IZA DP No. 4470

Thieves, Thugs, and Neighborhood Poverty

David Bjerk

October 2009 


\title{
Thieves, Thugs, and Neighborhood Poverty
}

\author{
David Bjerk \\ Claremont McKenna College \\ and IZA
}

\section{Discussion Paper No. 4470 \\ October 2009}

\author{
IZA \\ P.O. Box 7240 \\ 53072 Bonn \\ Germany \\ Phone: +49-228-3894-0 \\ Fax: +49-228-3894-180 \\ E-mail: iza@iza.org
}

\begin{abstract}
Any opinions expressed here are those of the author(s) and not those of IZA. Research published in this series may include views on policy, but the institute itself takes no institutional policy positions.

The Institute for the Study of Labor (IZA) in Bonn is a local and virtual international research center and a place of communication between science, politics and business. IZA is an independent nonprofit organization supported by Deutsche Post Foundation. The center is associated with the University of Bonn and offers a stimulating research environment through its international network, workshops and conferences, data service, project support, research visits and doctoral program. IZA engages in (i) original and internationally competitive research in all fields of labor economics, (ii) development of policy concepts, and (iii) dissemination of research results and concepts to the interested public.
\end{abstract}

IZA Discussion Papers often represent preliminary work and are circulated to encourage discussion. Citation of such a paper should account for its provisional character. A revised version may be available directly from the author. 


\section{ABSTRACT}

\section{Thieves, Thugs, and Neighborhood Poverty ${ }^{*}$}

This paper develops a model of crime analyzing how such behavior is associated with individual and neighborhood poverty. The model shows that even under relatively minimal assumptions, a connection between individual poverty and both property and violent crimes will arise, and moreover, "neighborhood" effects can develop, but will differ substantially in nature across crime types. A key implication is that greater economic segregation in a city should have no effect or a negative effect on property crime, but a positive effect on violent crime. Using IV methods, I show this implication to be consistent with the empirical evidence.

JEL Classification: K42, I38

Keywords: poverty, crime, neighborhood effects, segregation, instrumental variables, public housing

Corresponding author:

David Bjerk

Robert Day School of Economics and Finance

Claremont McKenna College

313 Bauer Center North

500 E. Ninth St.

Claremont, CA 91711

USA

E-mail: david.bjerk@cmc.edu

\footnotetext{
* Thanks to Jenny Hunt, Lance Lochner, Nicolas Marceau, John Donohue, Rucker Johnson, Jacob Klerman, Paco Martorell, Steve Raphael, Jeffrey Timberlake, and participants at the 2006 ALEA Meetings, the 2006 Workshop on Criminology and the Economics of Crime, as well as seminar participants at McMaster University, UQAM, York University, Rice University, University of Houston, Texas A\&M, Claremont McKenna College, RAND, The Goldman School at UC-Berkeley, and USC. Also, thanks to the Social Sciences Research Council (SSHRC) for financial support.
} 
"I don't care if I got money, or work Monday through Friday. I just go shoot a motherf*@er on the weekends. If that's what need to be done to keep my hood and my young ones around here safe, then that's what to get done" (quoted by Landesman, 2007).

\section{Introduction}

High rates of crime and violence in poor neighborhoods have been described by numerous scholars and journalists (Wilson, 1987; Krivo and Peterson, 1996; Kotlowitz, 1991; Patterson, 1991; Messner and Tardiff, 1986, to name just a few). However, the quote above from a man residing in a high-poverty housing project in south Los Angeles emphasizes that not only is crime a large part of life in high-poverty neighborhoods, but also that violent crimes may often serve a quite different purpose than basic property crime. Namely, while the motivation

for basic property crimes is generally purely monetary, becoming involved in violent crime may have a defensive motivation as well.

While this defensive motivation for violence has long been recognized by sociologists (Massey 1995; Anderson, 1999) and more recently by economists (Silverman, 2004), the mechanisms through which such motivations are exacerbated by individual and neighborhood poverty are less well understood. This paper attempts to explicitly model some of the key distinctions between participation in violent crimes versus basic property crimes, as well as the ways such participation decisions might be affected by an individual's own economic circumstances as well as the economic circumstances of his neighbors. The paper also considers the broader implications of greater residential segregation by income on the different types of crime.

While there may be numerous, and possibly quite complex, paths through which poverty and neighborhood characteristics may affect criminal behavior, the model developed here focuses on the impact of two quite simple assumptions. The first is simply that individuals 
incur diminishing marginal utility in money. The second is with respect to how violent crimes differ from basic property crimes. Specifically, when it comes to basic property crimes, I assume that by choosing to become a thief at any given period in time, an individual will simply have additional consumption beyond his legal income in that period. Alternatively, when it comes to violent crimes, I assume that individuals can choose to become either a thug (i.e. an individual who engages in violence) or a pacifist (i.e. an individual who does not engage in violence). This will mean that when two pacifists encounter one another in their neighborhood, they pass each other without incident. On the other hand, when a pacifist encounters a thug, the thug will attack him and take some of his money. However, when two thugs encounter one another, violence can still ensue but not necessarily with certainty. More importantly though, even when violence does ensue in such encounters, I assume that neither is able to take money from the other. In this way, choosing to be a thug can not only serve offensive purposes, allowing thugs to take money from pacifists in their neighborhood, but also be defensive in terms of ensuring ones' own money will not be taken by other thugs and potentially preventing an attack from occurring in the first place.

As will be shown below, the above assumptions are sufficient to ensure that poor individuals are more likely to become both thieves and thugs than a non-poor individuals. With respect to becoming a thief, the intuition is quite straightforward. The diminishing marginal utility of money assumption will mean a poor individual will value a fixed amount of money above and beyond his legal income more than will a rich individual, meaning that poor individuals will have a stronger incentive than non-poor individuals to steal, all else equal.

However, without additional assumptions, individual will be no more or less likely to become a thief if he lives in an extremely poor neighborhood versus a richer neighborhood, meaning no "neighborhood effects" when it comes to basic property crimes. However, if it is further assumed that the return to theft is greater when a greater fraction of one's neighbors are non-poor, neighborhood effects do arise, with individuals becoming more likely to become thieves the smaller the fraction of their neighbors that are poor. Therefore, all else equal, this 
model suggest that the degree to which a city's poor residents are residentially segregated from the city's non-poor residents will either have no effect or even a negative effect on the city's overall rate of basic property crime.

On the other hand, beyond the two basic assumptions discussed above, no further assumptions are necessary for neighborhood effects to arise with respect to violent crimes, as an individual's motivation to become a violent person (i.e. a thug) depends on his beliefs regarding the likelihood he will run into other thugs in his neighborhood, which in turn can depend on the level of poverty in his neighborhood. In fact, the model actually shows that the effect of neighborhood poverty on individual incentives to become a violent person gets increasingly stronger as the neighborhood poverty rate rises, which in turn implies thatt the more a city is segregated by poverty status, the greater will be the overall rate of violent crime - the opposite of what was true with respect to basic property crimes.

The latter part of the paper then empirically examines these two key implications of the model at the citywide level - namely that all else equal, greater economic segregation should have either a negligible or negative impact on basic property crimes such as burglary, larceny and motor vehicle theft, but should have a positive impact on interpersonal violent crimes such as robbery and aggravated assault. Using MSA level data for the United States from the year 2000, I find support for these implications. Moreover, these results become substantially stronger when I use instrumental variable methods to account for the possibility that economic segregation not only may impact crime, but crime may also impact the level of economic segregation. In particular, after I instrument for the economic segregation for each MSA using data on how public housing is allocated in the MSA, the fraction of local public funds in the MSA coming from the state or Federal government, the number of municipal governments in the MSA, and the number of larger rivers in the MSA, I find greater economic segregation has a negative but somewhat imprecisely estimated effect on burglary, a negligible effect on larceny and motor vehicle theft, and a positive and significant effect on robbery and aggravated assault. 


\section{Related Literature}

The theoretical model developed below relates to three particular streams of literature. The first is that of neighborhood effects, where individual behavior is directly affected by the characteristics and/or actions of his neighbors. For example, preferences for peer conformity may alter an individual's taste for engaging in crime (Glaeser, Sacerdote, and Sheinkman,1996; Brock and Durlauf, 2001), or an individual's information about payoffs to crime may evolve differently depending on the number of criminals in his neighborhood (Lochner and Heavner, 2002; Calvo-Armengol and Zenou, 2004; Calvo-Armengol, Verdier, and Zenou, 2007; Patacchini and Zenou, 2008). Somewhat relatedly, one individual's criminal behavior may create a positive externality for other potential criminals in that one person's criminal behavior taxes fixed police resources, which in turn lowers the probability of detecting/arresting other criminals (Ferrer, 2008). While these papers describe how "neighborhood effects" can arise given these assumptions, where a given individual's optimal behavior may be depend on which neighborhood he lives in, the model developed below takes a step back to consider how individual and neighborhood level poverty in and of themselves can affect criminal behavior even in absence of the types of assumptions discussed above.

The second area of research this model builds on is the literature on the relationship between crime and segregation. In this vein, Verdier and Zenou (2004) develop a model of labor market discrimination, crime, and racial segregation. owever, while their model can imply a correlation between crime and neighborhood income, it does not lead to "neighborhood effects" per say in that the actual characteristics of the an individual's neighbors do not

directly affect his own criminality. O'Flaherty and Sethi (2007) also model the relationship between racial segregation and a particular type of crime - namely robbery. An important contribution of this model is that criminal activity (namely robbery) and racial segregation are simultaneously determined, with both affecting the other. Moreover, individual criminal behavior is affected by the racial/income characteristics of his neighbors. However, a key implication of O'Flaherty and Sethi's model is that more segregated cities should experience 
lower robbery rates, as robbers would expect to meet more resistance to robbery attempts when a city is more segregated. As will be shown below, this is the opposite prediction from that generated in the model developed here, which potentially allows the models to be distinguished empirically.

Finally, the model developed below arguably most closely relates to the work describing how violence may play a strategic role. In particular, the sociological work of Anderson (1999) and Massey (1995) discusses how individuals adapt t high poverty isolated neighborhoods environments by becoming obsessively concerned with "respect" in order to lower the risk of their own criminal victimization, where such respect is maintained primarily through strategic use of force. Relatedly, Jankowski's (1991) argues that one of the central motivations for joining a gang is often self-protection, even if by joining a gang an individual commits to perpetrating violent acts against others. Silverman (2004) develops an explicit model of such strategic violence. In particular, within his model, if neighbors are sufficiently "connected" to each other and individuals do not discount their future too much, then some individuals who would prefer not to act violently toward others actually choose to engage in such behavior while young in order to gain a reputation as a street tough that will deter others from attacking them in the future.

While these papers consider the strategic role of violence, they generally do not make explicit why such behaviors are connected to an individual's own income and the income distribution in the individual's neighborhood, or how the overall amount of violence may be affected by the degree to which the poor are residentially segregated from the non-poor in the overall community. The model below attempts to develop these connections more formally. 


\section{Model of Crime, Poverty, and Neighborhood Com- position}

Consider a community made up of a large number of individuals who live for an infinite number of periods, where each individual can be classified as having either low income or high income. In the absence of committing any crime, assume low income individuals have $\omega_{\ell}$ dollars available for consumption each period, while high income individuals have $\omega_{h}$ dollars available for consumption each period, and individuals cannot save or borrow across periods. Let individuals value consumption in any given period according the a utility function $u$, where $u$ is an increasing strictly concave function in consumption, meaning individuals incur diminishing marginal utility in money. Finally, suppose the overall community can be divided up into a collection of neighborhoods, where each individual lives in one and only one neighborhood. Let $\lambda_{k}$ denote the fraction of residents in a given neighborhood $k$ who have low income (i.e. are poor), and let $\lambda$ denote the community-wide fraction of residents who have low income.

\subsection{Participation in Basic Property Crimes}

First consider an individual's decision to become a thief, or to engage in a property crime that does not involve a direct confrontation with other individuals (e.g. Burglary, Larceny, Motor Vehicle Theft). By becoming a thief, an individual $i$ adds $b$ units of additional consumption above and beyond the consumption possible though consuming his legal income that period, but also incurs a utility cost of $\epsilon_{p}^{i}$. In words, $\epsilon_{p}^{i}$ represents each individual $i$ 's disutility (or possibly his utility if $\epsilon_{p}^{i}<0$ ) associated with being a thief, such guilt or pleasure, as well as the expected disutility associated with the possibility of receiving a jail sentence. In order to focus only on the role income, assume that $\epsilon_{p}^{i}$ is an i.i.d. random draw from a normal distribution with mean $\mu_{p}$ and variance $\sigma_{p}^{2},{ }^{1}$ and therefore is independent across individuals,

\footnotetext{
${ }^{1}$ The assumption that $\epsilon^{i}$ is distributed normally is used for simplicity only. Proposition 3 and Proposition 4 employ this assumption, but both will generally hold under most any bell-shaped distributional assumption
} 
meaning individual's preferences are not influenced directly by their neighbors' preferences or characteristics. This parameter will be referred to as each individual's "criminal propensity," with a lower $\epsilon_{p}^{i}$ indicating a higher criminal propensity.

Given the discussion from above, an individual chooses to become a thief if and only if $u\left(\omega^{i}+b\right)-\epsilon_{p}^{i} \geq u\left(\omega^{i}\right)$, meaning the equilibrium fraction of individuals of income level $\omega_{j}$ (for $j \in\{\ell, h\}$ ) living in neighborhood $k$ who choose to become thieves in any given period equals

$$
\pi_{j}^{*}=\Phi_{p}\left(u\left(\omega_{j}+b\right)-u\left(\omega_{j}\right)\right)
$$

where $\Phi_{p}$ is the cumulative distribution for the normally distributed random variable $\epsilon_{p}^{i}$.

Because of the strict concavity of the $u$ function, it is straightforward to see that $\pi_{h}^{*}<\pi_{\ell}^{*}$. In words, because the utility associated with any fixed monetary payoff from stealing is lower for high income individuals, high income individuals are less likely to become thieves. Hence, the greater the overall fraction of a neighborhood who are of low income, the greater the fraction of the neighborhood who become thieves. This argument also holds at the community-wide level. Therefore, in this simple model, the rate of basic property crimes committed in a neighborhood (or a whole community), should be increasing in the fraction of neighborhood (community) made up of poor individuals. A second thing to notice about $\pi_{j}^{*}$ as given in equation (1) is that it does not depend on $\lambda_{k}$. In words, the probability that an individual becomes a thief does not depend on the income of his neighbors, meaning there are no "neighborhood effects" with respect to basic property crimes without making further assumptions. Therefore, after controlling for the overall fraction of the community made up of poor individuals, the level of economic segregation in the community as a whole should have no direct effect on the overall rate of basic property crimes.

One reasonable extension is to assume that the monetary benefit to being a thief is greater when fewer of one's neighbors are poor, or if the monetary benefit to being a thief is given for $\epsilon^{i}$. 
by $b\left(\lambda_{k}\right)$, then $b^{\prime}\left(\lambda_{k}\right)<0$. In this case, equation (1) would become

$$
\pi_{j}^{*}\left(\lambda_{k}\right)=\Phi_{p}\left(u\left(\omega_{j}+b\left(\lambda_{k}\right)\right)-u\left(\omega_{j}\right)\right)
$$

Since $b\left(\lambda_{k}\right)$ is decreasing in $\lambda_{k}$, the above equation implies that the fraction of individuals of any given income level $j$ who choose to become thieves is decreasing in $\lambda_{k}$. Therefore, when the monetary benefit to being a thief depends on the economic status of one's neighbors, there will exist neighborhood effects with respect to becoming a thief. Moreover, note that the change in expected criminality from moving an individual of income level $\omega_{j}$ from a neighborhood $k$ to a richer neighborhood $k^{\prime}$ (meaning $\lambda_{k}<\lambda_{k^{\prime}}$ and $b\left(\lambda_{k}\right)>b\left(\lambda_{k^{\prime}}\right)$ ), will equal

$$
\Delta \pi_{j}^{*}=\Phi_{p}\left(u\left(\omega_{j}+b\left(\lambda_{k}\right)\right)-u\left(\omega_{j}\right)\right)-\Phi_{p}\left(u\left(\omega_{j}+b\left(\lambda_{k^{\prime}}\right)\right)-u\left(\omega_{j}\right)\right) .
$$

Further note that the concavity of the $u$ function implies $\left[u\left(\omega_{j}+b\left(\lambda_{k}\right)\right)-u\left(\omega_{j}\right)\right]-\left[u\left(\omega_{j}+\right.\right.$ $\left.\left.b\left(\lambda_{k^{\prime}}\right)\right)-u\left(\omega_{j}\right)\right]$ will be larger when $\omega_{j}=\omega_{\ell}$ than when $\omega_{j}=\omega_{h}$. Therefore, a sufficient condition for $\Delta \pi_{\ell}^{*}>\Delta \pi_{h}^{*}$ is for $\Phi$ to be weakly convex when evaluated at or before $u\left(\omega_{\ell}+\right.$ $\left.b\left(\lambda_{k}\right)\right)-u\left(\omega_{\ell}\right)$. Given $\Phi_{p}$ is the cdf of a normal distribution, this would be true for example if $\pi_{\ell}^{*}(0) \leq 0.5$, or if less than half of the poor individuals would choose to become thieves even if they were the only poor person in their neighborhood.

Recalling that $\Delta \pi_{j}^{*}$ denotes the expected change in criminality with respect to basic property crimes from moving an individual of income level $\omega_{j}$ from a richer to a poorer neighborhood, we can infer that an important implication of $\Delta \pi_{\ell}^{*}$ being greater than $\Delta \pi_{h}^{*}$ is that there will be bigger increase in expected criminality when moving a poor individual from a poorer neighborhood to a richer neighborhood than would be offset by the decrease in expected criminality from moving a rich individual from the richer neighborhood to the poorer neighborhood. This in turn implies that when the monetary benefit to committing a given basic property crime is inversely related to the fraction of the neighborhood that is 
poor, less segregation will actually increase this type of basic property crime and vice versa.

In summary, the simple model laid out in this section shows that in the absence of assuming preferences, information regarding payoffs to crime, or policing depend on the behavior or characteristics of one's neighbors, greater segregation by income will either have no effect, or a negative effect on community-wide basic property crimes, depending on whether the monetary benefit of basic property crime becomes greater the neighborhood poverty rate decreases.

\subsection{Participation in Interpersonal Violent Crime}

Now consider crimes against persons, such as muggings, robberies, and assaults. In modelling these crimes, assume each individual decides whether to be a "thug" or a "pacifist," then proceeds to encounter other individuals in his neighborhood at a rate of one person per period. By choosing to be a pacifist, an individual commits to acting passively when encountering anyone in his neighborhood. Alternatively, by choosing to be a thug, an individual commits to violently attacking any pacifist he encounters in his neighborhood and having a violent interaction with another thug with probability $p \in[0,1]$. Therefore, when a pacifist and a thug encounter each other, the one-sided violence will allow the thug to successfully rob the pacifist, thereby increasing the thug's consumption in that period by $b$, while decreasing the pacifist's consumption that period by $b$ and further imposing a cost of $c$ on the pacifist due to pain and suffering. ${ }^{2}$ On the other hand, when two thugs encounter each other violence arises with probability $p$, and when it does, both individuals will still incur a cost of $c$ due to pain and suffering but no money will change hands. Finally, when two pacifists encounter each other, no violence takes place, meaning no money changes hands and no pain and suffering arises.

\footnotetext{
${ }^{2}$ I assume that $b$ does not depend on the income of one's victim. While the model is robust to loosening this assumption a little bit, I feel that such an assumption is generally justified. Afterall, it is not clear that poor individuals carry less cash on them than do rich individuals, especially since poor individuals are less likely to store their wealth in bank accounts or credit cards. A similar assumption and justification is made by O'Flaherty and Sethi (2007).
} 
The above assumptions can be motivated two ways. First, choosing to be a thug can be interpreted as an individual learning the fighting skills and/or obtaining the weapons necessary to take possessions from pacifists, who do not have such skills and/or weapons. However, since other thugs also have fighting skills and/or weapons, thugs cannot take possessions from each other, but will incur substantial pain and suffering when they fight. A second, complementary interpretation is that choosing to be a thug is equivalent to joining a street gang, where gang members take property from the non-gang members they encounters in their neighborhood, while at the same time must periodically engage in violence when encountering rival gang members, but does not lose their own property in such altercations. Such motivation is consistent with some of the ethnographic literature on gangs. For example, in summarizing the work of Savitz, Rosen, and Lalli (1980), Spergel (1990) states “(j)oining a gang may also result from rational calculations to achieve personal security, particularly for males, in certain neighborhoods."

Finally, analogous to the basic property crime model, by choosing to be a thug an individual $i$ must further incur a utility $\operatorname{cost} \epsilon_{v}^{i}$ each period, where once again $\epsilon_{v}^{i}$ is drawn from an normal distribution with mean $\mu_{v}$ and variance $\sigma_{v}^{2}$ and is independent across individuals (but is fixed for a given individual across periods). As before, this criminal propensity parameter $\epsilon_{v}^{i}$ captures the effort and any feelings of guilt (or pleasure) associated with being a thug and engaging in violence, as well as the expected disutility of being arrested and punished for being a thug.

The above assumptions mean that the expected utility for any given period for an individual $i$ of income level $\omega_{j}$ living in neighborhood $k$ associated with becoming a thug is given by

$$
\hat{\pi}_{k}\left[u\left(\omega_{j}\right)-p c\right]+\left(1-\hat{\pi}_{k}\right) u\left(\omega_{j}+b\right)-\epsilon_{v}^{i},
$$

where $\hat{\pi}_{k}$ is the individual's beliefs concerning the likelihood he encounters a thug as opposed to a pacifist in his neighborhood in the period. Alternatively, the expected utility from being 
a pacifist for any given period for an individual $i$ of income level $\omega_{j}$ living in neighborhood $k$ is given by

$$
\hat{\pi}_{k}\left[u\left(\omega_{j}-b\right)-c\right]+\left(1-\hat{\pi}_{k}\right) u\left(\omega_{j}\right),
$$

where, once again, $\hat{\pi}_{k}$ is the individual's beliefs concerning the relative frequency he will encounter a thugs as opposed to pacifists in his neighborhood $k$.

Given the above expected utilities, we can derive that optimal behavior for an individual $i$ of income level $j$ living in neighborhood $k$ is to become a thug if and only if

$$
\hat{\pi}_{k}\left[u\left(\omega_{j}\right)-u\left(\omega_{j}-b\right)+(1-p) c\right]+\left(1-\hat{\pi}_{k}\right)\left[u\left(\omega_{j}+b\right)-u\left(\omega_{j}\right)\right] \geq \epsilon_{v}^{i} .
$$

Like with basic property crimes, the above expression indicates that it will generally be those with a low $\epsilon_{v}^{i}$, meaning those with high criminal propensities, who will choose to become thugs.

In order to further simplify equation $(2)$, define $\delta_{t}\left(\omega_{j}\right)$ to equal $u\left(\omega_{j}\right)-u\left(\omega_{j}-b\right)$. In words, $\delta_{t}\left(\omega_{j}\right)+(1-p) c$ is the opportunity cost incurred by not being a thug when encountering a thug, for an individual with income $\omega_{j}$. Similarly, define $\delta_{p}\left(w_{j}\right)$ to equal $u\left(\omega_{j}+b\right)-u\left(\omega_{j}\right)$, meaning $\delta_{p}\left(\omega_{j}\right)$ is the opportunity cost incurred by not being a thug when encountering a pacifist, for an individual with income $\omega_{j}$.

Given these definitions, equation (2) becomes

$$
\hat{\pi}_{k}\left(\delta_{t}\left(\omega_{j}\right)+(1-p) c\right)+\left[1-\hat{\pi}_{k}\right] \delta_{p}\left(\omega_{j}\right) \geq \epsilon_{v}^{i}
$$

This equation highlights the important components with respect to the decision individuals make regarding whether or not to become a thug in this environment. Namely, the fraction of individuals in a neighborhood choosing to become thugs is increasing in both the monetary benefit that can be obtained from doing so (i.e. $\left.\delta_{p}\left(\omega_{j}\right)\right)$, as well as the monetary and pain and suffering cost that can be avoided by doing so (i.e. $\left.\delta_{t}\left(\omega_{j}\right)+(1-p) c\right)$. This latter benefit 
to being a thug is one thing that makes the decision to become a thug different from the decision to become a thief. Moreover, also unlike the decision regarding whether or not to become a thief, the decision to become a thug depends on the individual's beliefs regarding the fraction of other individuals in the neighborhood who are going to be thugs (i.e. $\hat{\pi}_{k}$ ).

From equation (3), we can now derive the fraction of individuals of income level $\omega_{j}$ living in neighborhood $k$ choosing to be a thug to be

$$
\pi_{j}=\Phi_{v}\left(\hat{\pi}_{k}\left(\delta_{t}\left(\omega_{j}\right)+(1-p) c\right)+\left[1-\hat{\pi}_{k}\right] \delta_{p}\left(\omega_{j}\right)\right),
$$

where $\Phi_{v}$ again denotes the cdf of a normal distribution. For simplicity, I will refer to the fraction of individuals of a given group who choose to be a thug as the violent criminal participation rate for this group.

A Rational Expectations Equilibrium in this environment will be for individuals to behave optimally with respect to becoming a thug given their beliefs, and for their beliefs to be consistent with the resulting state of the world given each other individual behaves optimally. If we define $\pi_{j}^{*}\left(\lambda_{k}\right)$ as the equilibrium criminal participation rate for individuals of income level $j$ living in a neighborhood $k$, we can state the following Theorem.

Theorem 1 For any $\lambda_{k} \in[0,1]$, there exists a Rational Expectations Equilibrium characterized by violent criminal participation rates $\left\{\pi_{\ell}^{*}\left(\lambda_{k}\right), \pi_{h}^{*}\left(\lambda_{k}\right)\right\}$ and beliefs $\hat{\pi}_{k}=\pi^{*}\left(\lambda_{k}\right)=$ $\lambda_{k} \pi_{\ell}^{*}\left(\lambda_{k}\right)+\left(1-\lambda_{k}\right) \pi_{h}^{*}\left(\lambda_{k}\right)$, such that the following two equations hold:

$$
\begin{aligned}
& \pi_{\ell}^{*}\left(\lambda_{k}\right)=\Phi_{v}\left(\pi^{*}\left(\lambda_{k}\right)\left(\delta_{t}\left(\omega_{\ell}\right)+(1-p) c\right)+\left[1-\pi^{*}\left(\lambda_{k}\right)\right] \delta_{p}\left(\omega_{\ell}\right)\right), \\
& \pi_{h}^{*}\left(\lambda_{k}\right)=\Phi_{v}\left(\pi^{*}\left(\lambda_{k}\right)\left(\delta_{t}\left(\omega_{h}\right)+(1-p) c\right)+\left[1-\pi^{*}\left(\lambda_{k}\right)\right] \delta_{p}\left(\omega_{h}\right)\right),
\end{aligned}
$$

Proof. In Proofs Appendix (available upon request). 
Given the existence of an equilibrium, ${ }^{3}$ a first thing to note is that the strict concavity of the $u$ function implies that $\left(\delta_{t}\left(\omega_{\ell}\right)+(1-p) c\right)>\left(\delta_{t}\left(\omega_{h}\right)+(1-p) c\right)$ (or equivalently $\delta_{t}\left(\omega_{\ell}\right)>\left(\delta_{t}\left(\omega_{h}\right)\right)$, and $\delta_{p}\left(\omega_{\ell}\right)>\delta_{p}\left(\omega_{h}\right) .4$ In words, low income individuals will have a greater incentive to become thugs than will higher income individuals all else equal. The intuition is similar to that with respect to basic property crimes. Since each individual's utility function exhibits diminishing marginal utility in consumption (and therefore income), the greater the individual's income each period, the smaller is the utility lost from getting a relatively small amount of money taken from them in any given period, and the smaller is the utility gained by taking a relatively small amount of money from someone else.

These differing incentive across income types leads to Proposition 1.

Proposition 1 In any neighborhood $k$, a greater fraction of low income individuals will participate in interpersonal violent crimes (i.e. be thugs) than high income individuals, or $\pi_{\ell}^{*}\left(\lambda_{k}\right)>\pi_{h}^{*}\left(\lambda_{k}\right)$

Proof. In Proofs Appendix (available upon request).

The next thing to examine is how the likelihood of becoming a thug depends on the poverty rate of one's neighbors (i.e. $\lambda_{k}$ ), which leads to Proposition 2.

Proposition 2 Given there is sufficient variation in violent criminal propensity over the population (namely $\sigma_{v}>\frac{\delta_{t}\left(\omega_{\ell}\right)-\delta_{p}\left(\omega_{\ell}\right)}{\sqrt{2 \pi}}$ ), then for both high and low income individuals, the fraction choosing to participate in interpersonal violent crimes is increasing in the fraction of their neighborhood that has low income, or $\frac{\partial \pi_{j}^{*}\left(\lambda_{k}\right)}{\partial \lambda_{k}}>0$ for $j=h, \ell$.

\footnotetext{
${ }^{3}$ Without further assumptions, I cannot rule out the potential existence of multiple equilibria. However, as can be confimed in the proofs to the the Propositions below, the Propositions will apply to any potential equilibrium.

${ }^{4}$ Technically, this result is only guaranteed when $\omega_{h}-b>\omega_{\ell}+b$. In other words, when the changes in wealth associated with mugging or being mugged are small compared to the overall income differences between high income and low income individuals.
} 
Proof. In Proofs Appendix (available upon request).

Proposition 2 shows that, in this model, an individual with income level $j$ is more likely to become a thug if he lives in a relatively poor neighborhood than in a relatively rich neighborhood, meaning there exist neighborhood effects with respect to violent crime. Intuitively, when an individual expects a relatively high fraction of his neighbors to be thugs (as he would in a high poverty neighborhood), his own incentive to become a thug is primarily defensive, in the sense of being able to prevent other thugs from taking his property. Alternatively, when an individual expects very few of his neighbors to be thugs (as he would in a low poverty neighborhood), his own incentive to become a thug is primarily to offensive, in the sense of being able to successfully take property from others. Due to the diminishing marginal utility of consumption, we know $\delta_{t}\left(\omega_{j}\right)+(1-p) c>\delta_{p}\left(\omega_{j}\right)$ for $j=h, \ell$ and $p \in[0,1]$ (as can also be seen in Figure 1), meaning the defensive incentive for becoming a thug in a poor neighborhood is greater than the offensive incentive in a richer neighborhood.

Pushing the model a little bit further, we can examine whether the strength of this neighborhood effect (i.e. $\frac{\partial \pi_{j}^{*}\left(\lambda_{k}\right)}{\partial \lambda_{k}}$ ) differs by the income level of the individual. This leads to Proposition 3.

Proposition 3 If $\pi_{\ell}^{*}(1) \leq 0.5$, the neighborhood effect will be stronger for low income individuals than high income individuals, or $\frac{\partial \pi_{\ell}^{*}\left(\lambda_{k}\right)}{\partial \lambda_{k}}>\frac{\partial \pi_{h}^{*}\left(\lambda_{k}\right)}{\partial \lambda_{k}}$.

Proof. In Proofs Appendix (available upon request).

Intuitively, from Figure 1, we know that regardless of income level, the opportunity cost associated with not being a thug when encountering a pacifist is greater than the opportunity cost of not being a thug when encountering another thug. This difference in opportunity costs accounts for the greater likelihood of becoming a thug in high poverty neighborhoods (where the likelihood of encountering a thug is high) than in lower poverty neighborhoods. 
Moreover, the strict concavity of the $u$ function implies that this difference in opportunity costs is greater for low-income individuals than high-income individuals (as can also be seen in Figure 1). Thus, low-income individuals will be more influenced by the income characteristics of their neighbors than will higher-income individuals when it comes to committing violent crimes. ${ }^{5}$

We can now analyze how the income distribution within a neighborhood, as well as how income is distributed across neighborhoods within the overall community, affect the rate of interpersonal violent crime. To start this analysis, first recall that the equilibrium fraction of individuals in any particular neighborhood $k$ choosing to become thugs is given by $\pi^{*}\left(\lambda_{k}\right)=\lambda_{k} \pi_{\ell}^{*}\left(\lambda_{k}\right)+\left(1-\lambda_{k}\right) \pi_{h}^{*}\left(\lambda_{k}\right)$. Taking the derivative of this equation and re-arranging gives

$$
\frac{\partial \pi^{*}\left(\lambda_{k}\right)}{\partial \lambda_{k}}=\left(\pi_{\ell}^{*}\left(\lambda_{k}\right)-\pi_{h}^{*}\left(\lambda_{k}\right)\right)+\lambda_{k} \frac{\partial \pi_{\ell}^{*}\left(\lambda_{k}\right)}{\partial \lambda_{k}}+\left(1-\lambda_{k}\right) \frac{\partial \pi_{h}^{*}\left(\lambda_{k}\right)}{\partial \lambda_{k}} .
$$

From Proposition 1 we know that the first expression in parentheses in the above equation is positive, and from Proposition 2 we know that the second and third expressions in the above expression are also positive. Therefore, if we assume the overall rate of interpersonal violent crime within a neighborhood at any given point time is a strictly increasing function of the fraction of the residents in the neighborhood who are thugs at that time, then increasing the fraction of the neighborhood made up of low income individuals will increase the overall rate of interpersonal violent crime in the neighborhood.

Furthermore, note that if we take the second derivative of $\pi^{*}\left(\lambda_{k}\right)$ and re-arrange, we obtain

\footnotetext{
${ }^{5}$ The sufficient condition for this result, namely $\pi_{\ell}^{*}(1) \leq 0.5$, essentially says that this result will always hold if a relatively large fraction of poor individuals incur sufficient disutility from choosing to engage in the thug life such that they will still choose not to become thugs even if all of their neighbors are poor (i.e. a large fraction of individuals have a low criminal propensity or high $\epsilon_{v}^{i}$ ). It is worth noting that this is a sufficient condition for Proposition 3 to hold, but is not necessary. If we drop the assumption that $\epsilon^{i}$ is normally distributed, a sufficient condition for Proposition 4 is that the cumulative distribution of $\epsilon^{i}$ is simply weakly convex prior to $\pi_{\ell}^{*}(1)$.
} 


$$
\frac{\partial^{2} \pi^{*}\left(\lambda_{k}\right)}{\partial \lambda_{k}^{2}}=2\left(\frac{\partial \pi_{\ell}^{*}\left(\lambda_{k}\right)}{\partial \lambda_{k}}-\frac{\partial \pi_{h}^{*}\left(\lambda_{k}\right)}{\partial \lambda_{k}}\right)+\lambda_{k} \frac{\partial^{2} \pi_{\ell}^{*}\left(\lambda_{k}\right)}{\partial \lambda_{k}^{2}}+\left(1-\lambda_{k}\right) \frac{\partial^{2} \pi_{h}^{*}\left(\lambda_{k}\right)}{\partial \lambda_{k}^{2}}
$$

From Proposition 3, we know the expression in parentheses in the above equation is positive. Moreover, as long as we again assume $\pi_{\ell}^{*}(1) \leq 0.5$ and $\sigma_{v}>\frac{\delta_{t}\left(\omega_{\ell}\right)-\delta_{p}\left(\omega_{\ell}\right)}{\sqrt{2 \pi}}$, both of the latter two terms in the above expression are also positive, implying $\frac{\partial^{2} \pi^{*}\left(\lambda_{k}\right)}{\partial \lambda_{k}^{2}}>0 .{ }^{6}$ This leads to Proposition 4.

Proposition 4 The rate of interpersonal violent crime in the community as a whole is increasing in the degree to which its neighborhoods are segregated by income.

Proof. Given $\frac{\partial \pi^{*}\left(\lambda_{k}\right)}{\partial \lambda_{k}}>0$ and $\frac{\partial^{2} \pi^{*}\left(\lambda_{k}\right)}{\partial \lambda_{k}^{2}}>0$, we know the fraction of a neighborhood that chooses to become thugs is an increasing strictly convex function of the fraction of the neighborhood that is poor. Therefore, for any given community wide fraction poor $\lambda$, the interpersonal crime rate in the overall community is minimized when all neighborhoods have the same fraction of the poor. Alternatively, the rate of interpersonal crime in the community as a whole becomes greater the more its neighborhoods are segregated by income.

The intuition for Proposition 4 comes from Proposition 3, which showed that neighborhood effect more strongly influences poor individuals than rich individuals. Therefore, the rate of interpersonal violent crime should necessarily be higher the more poor individuals are segregated from richer individuals all else equal. Note that just the opposite was true with respect to the basic property crime model developed above.

In summary, this model reveals the important role of poverty at both the individual and neighborhood level can play when it comes to crime rates. The model shows how even with very few assumptions, the strategic role of violence can interact with neighborhood poverty rates to create neighborhood effects on individual decisionmaking. Notably, a key feature of this model is that it implies that neighborhood effects with respect to violent crime are likely to be more pronounced and different in nature than any that might arise with respect

\footnotetext{
${ }^{6}$ Proof in Proofs Appendix which is available from the author upon request.
} 
to basic property crime. This is in contrast to the other models of neighborhood effects highlighted at the beginning of Section 2, where the neighborhood effects that arise in those models would not necessarily differ across crime types.

\section{Empirically Evaluating the Model}

While the model presented above was in many ways quite simplistic, abstracting from many other potentially important determinants of crime rates in cities, there is still value in attempting some empirical analysis of the propositions of the model. While it would be optimal to empirically evaluate all of these propositions, there are a variety of hurdles one must face in attempting to do so. These hurdles are highest with respect to testing the individual-level propositions 1 - 3. Mostly notably, there are severe data constraints as one would need individual level data regarding criminal participation distinguished by crime type and frequency, own legal income, as well as information regarding the income characteristics of each individual's neighbors. A reasonably large and representative dataset containing such data is not readily available to my knowledge.

Given these data constraints, I will focus on the key community-level implications inherent in Section 3.2 and Proposition 4, or that, all else equal, greater economic segregation in a city should lead to higher rates of violent interpersonal crimes but have negligible or even a negative impact on basic property crime rates. These community-level implications do not face the same data constraints as the individual-level implications since information on criminal activity by crime type, as well as measures of economic segregation (as well as a host of other community-level characteristics) are readily available by MSA. However, there still exists a potentially important endogeneity/simultaneity concern that was not explicitly incorporated into the theoretical model. Namely, while the degree to which a city is segregated by poverty status may have an impact on different types of crime for the reasons specified in the model, it may also be true that greater criminal activity affects the level 
of segregation by poverty status in overall community. Therefore, given the model treated the level of segregation in a community as exogenous, I will attempt to focus on plausibly exogenous variation in segregation across cities using instrumental variable methods.

As alluded to in the previous paragraph, the analysis that follows will be done at the MSA/PMSA level ("MSAs" from here on). The data and varibles I use for this analysis are described below.

\section{FBI Uniform Crime Reports (UCR)}

The FBI Uniform Crime Reporting Program is a nationwide program covering roughly 94 percent of the total U.S. population, and 96 percent of the population living in MSAs. (Federal Bureau of Investigation, 2000). ${ }^{7}$ In this analysis, I use the 2000 FBI UCR data to look at separately at the five most common Index crimes - robbery, aggravated assault, burglary, larceny-theft, and motor vehicle theft. ${ }^{8}$ A major distinction between these crime categories is that Aggravated Assault and Robbery are defined to be violent crimes involving a direct confrontation with the victim, while Burglary, Larceny, and Motor Vehicle Thefts are defined as non-violent property crimes that explicitly do not involve a direct confrontation with the victim (Federal Bureau of Investigation, 2000). ${ }^{9}$ Therefore, I will refer to Aggravated Assault and Robbery as "violent interpersonal crimes," and Burglary, Larceny, and Motor Vehicle Thefts as "basic property crimes."

I also use the FBI UCR data from 1999 to measure the number of officers per 1000 residents in each city, to account for differences in police presence across cities. Moreover, since the FBI UCR crime data are reported at the county level, I determined crime rates and officer rates for each MSA by aggregating all relevant data for counties that fall within a particular MSA. Because most counties either fall in one MSA or fall in zero MSAs, this

\footnotetext{
${ }^{7}$ This data was made available through the National Archive for Criminal Justice Data (NACJD) and the Inter-University Consortium for Political and Social Research (ICPSR) study \#3451.

${ }^{8} \mathrm{I}$ do not look at the two other Index crimes - rape and murder-because the number of these crimes are relatively small, especially in smaller cities, making the rates somewhat uninformative. In particular, in many smaller cities there are less than 5 of such crimes reported in a given year, meaning for example that one more murder in a given year will increase the murder rate in that city by 20 percent or more.

${ }^{9}$ Car-jacking, or taking an individual's car by threat or force, is counted as robbery, not a motor vehicle theft.
} 
generally provided accurate MSA crime information. However, several New England counties are divided between two or more distinct MSAs. Since I could not determine which MSA to assign the reported crimes in these counties to, I had to exclude these New England MSAs that contained shared counties from the analysis. ${ }^{10}$ Finally, I dropped all MSAs with fewer than 150,000 residents since their crime rates, especially for violent crime, fluctuate substantially from year to year even though there are relatively modest changes in the number of crimes.

\section{MSA Population Characteristics}

Data regarding MSA population characteristics come for the most part from the 2000 United States Census Summary File 3. I use these data to obtain measures of a variety of demographic chracteristics for each MSA (see Table I for particular variables). I also use data from the Department of Housing and Urban Development's "A Picture of Subsidized Households - 1998" to determine the fraction of households in each MSA that receive housing assistance. Finally, to control for the potential effects of weather on criminal activity (see Jacob, Lefgren, and Moretti, 2007), I determined the average number of very hot days (i.e. temperature of 90 degrees or higher) per 100 days for each state, as well as the average number of very cold days (i.e. temperature of 32 degrees or lower) per 100 days for each state using data from the National Climatic Data Center.

Table I summarizes all of the above variables for the sample used in this analysis.

\subsection{The Correlation between Economic Segregation and Crime}

While there exist several plausible ways to measure the level of income segregation within a city, I primarily employ what the isolation index. ${ }^{11}$ This index attempts to measure

\footnotetext{
${ }^{10}$ This criteria excluded the following MSAs: Bangor ME, Boston MA-NH, Burlington VT, Hartford CT, Lewiston-Auburn ME, Manchester NH, Pittsfield MA, Portland ME, Portsmouth-Rochester NH-ME, Springfield MA. The Miami FL MSA, the Bloomington-Normal IL MSA, and the Champaign-Urbana IL MSA were also dropped from the sample because the FBI UCR reports did not provide crime data for these MSAs in 2000.

${ }^{11}$ All segregation measures used in this paper were computed using the Census Summary File 3 data discussed previously.
} 
the extent to which individuals of one group are only exposed to one another, rather than members of the other group, in their neighborhoods (Massey and Denton 1988). In the context of segregation by poverty status, this index is essentially computed to be the fraction poor in the census tract occupied by the average poor individual in that MSA, and is given by the following formula:

$$
\text { Poverty Isolation Index }=\sum_{i=1}^{N} \frac{\text { poor }_{i}}{\text { poor }_{\text {total }}} \frac{\text { poor }_{i}}{\text { persons }_{i}}
$$

where $i$ denotes census tract. The higher this index is, the greater the level of segregation.

Looking at this segregation statistic when it is computed using all census tracts in each MSA reveals a potentially problematic issue, namely that among the twenty MSAs with the highest Poverty Isolation Index are College Station TX, Gainsville FL, Athens GA, Talahassee FL, Lafayette IN, Madison WI, Provo-Orem UT, and Las Cruces NM; all moderate to small MSAs containing large universities. The concern this raises is that full-time students who do not live in dormitories will generally be counted as poor, since they earn little or no income while in school. Moreover, such students tend to live almost exclusively in census tracts surrounding their University, causing MSAs with relatively high college student populations to appear relatively segregated by poverty status, but not in the way we generally are attempting to capture. Therefore, I also computed the Poverty Isolation Index for each MSA excluding those census tracts containing over 60 percent students. This will be the preferred measure of Poverty Segregation, however, as I will also show, results do not differ substantively by using Poverty Isolation Indices computed using all census tracts.

We can begin by looking at the relationship between crime and poverty segregation by using simple OLS specifications, regressing the MSA crime rate, for each type of crime separately, on the Poverty Isolation Index for the MSA and a variety of other MSA characteristics. Table II shows separate specifications for each type of crime, where the dependant variable is the rate of that crime per 100,000 residents, standardized to have a mean of zero and standard deviation of one. I use these standardized rates in order to facilitate comparing 
magnitudes across crimes, as the overall rates per 100,000 residents differ dramatically across crimes (as can be seen in Table I).

Looking at the first row of Table II, we can see that conditional on the MSA level characteristics, the correlation between segregation by poverty status and crime rates is relatively weak across all crime categories, but there is some evidence that segregation by poverty status is positively correlated with motor vehicle theft, robbery, and aggravated assault. $^{12}$

While these OLS results reveal some small differences in the correlation between poverty segregation and crime across different types of crime, these results are not necessarily very informative about the degree to which such economic segregation actually affects MSA-wide crime rates for these different types of crimes. In particular, as alluded to previously, the level of segregation in an MSA may be endogenous since people generally have substantial choice about where to live within a city and crime rates might affect this decision.

Such selection may bias the causal interpretation of the OLS results for several reasons. To take one example, Cullen and Levitt (1999) argue that rising crime rates may lead to flight from central cities, especially by the wealthy (and white). This means that any positive relationship between crime and segregation may arise not because greater segregation increases crime, but because greater crime leads to greater economic and racial segregation. Therefore, the OLS results presented previously may be upwardly biased.

Alternatively, as violent crime increases in a city, for example as gangs become more prominent, individuals living in the neighborhoods where these gangs operate have a greater incentive to take on the expenses associated with moving. Indeed, escaping from gangs and

\footnotetext{
${ }^{12}$ I also constructed Racial Isolation Indices for each MSA (using all census tracts). The coefficients on the Racial Isolation Index in specifications otherwise ananlogous to those in Table II are insignificantly different from zero at any standard level of significance in the Burglary, Larceny, and Motor Vehicle Theft specifications. However, the coefficients on the Racial Isolation Index are positive and significant at the 1 percent level in the Robbery and Aggravated Assault specifications. Like the coefficients in Table II, these coefficients were also relatively small in magnitude, with the coefficients indicating that a one standard deviation in the Racial Isolation Index is correlated with a 0.25 and 0.31 standard deviation increase in Robbery and Aggravated Assault rates respectively - findings consistent with Shihadeh and Flynn (1996). The estimated coefficients on the other variables are almost identical to those in Table II.
} 
crime was the primary reason participants in the MTO housing relocation program gave for signing up for the program (Kling, Ludwig, and Katz, 2005). Given that these neighborhoods where violence and gang activity are greatest are often the poorest neighborhoods in a city, those emigrating from these neighborhoods will generally be poorer than the residents of the neighborhoods they move to. Therefore, it is also possible that as crime increases, a city becomes somewhat less economically segregated than it would be otherwise, meaning the OLS results discussed previously could also be downwardly biased. ${ }^{13}$

\subsection{Controlling for the Potential Endogeneity of Segregation}

To overcome the potential simultaneity bias we must find some characteristics that vary across Metropolitan areas that affect current income segregation, but can be credibly excluded from having any direct relationship to current levels of criminal activity. Given the existence of such variables, we can then use them as instruments in Two-stage Least Squares (2SLS) approach. ${ }^{14}$

The first instrument for segregation by poverty status that I employ is the fraction of public housing assistance that was allocated in the form of apartments in government owned public housing structures as opposed to allocated via Section 8 housing vouchers or certificates (or other types of subsidies to non-government property owners). The data used to create this instrument once again comes from the HUD's "A Picture of Subsidized Households - 1998" described above. By design, public housing structures group poor individuals together to a greater extent than do housing vouchers which can generally be used anywhere in the city. Indeed, the HUD data shows that the census tracts surrounding Public Housing Structures are almost 40 percent poor on average, compared with an average of around 20 percent poor for census tracts surrounding those units procured via vouchers or certificates.

\footnotetext{
${ }^{13}$ For more formal and detailed discussions of racial and economic segregation that are not related to crime, see Sethi and Somanathan (2004) and Bayer, McMillan, and Rueben (2004).

${ }^{14}$ Optimally, one might want to look at the relationship between changes in economic segregation over time and changes in crime rates. However, such a method would not allevaite the basic endogeneity concern on its own, and therefore would require time-varying instruments for economic segregation. As will be seen below, the instruments used here are not time varying.
} 
Moreover, since public housing projects constitute a stock of facilities that generally have existed for a considerable number of years prior to the year 1998 (the year in which the measures come from for this analysis), it is unlikely that the overall fraction of housing assistance provided via apartments in public housing projects in 1998 was directly related to the factors determining the crime conditions in the MSA in the period around 2000, especially after controlling for a variety of other MSA characteristics (including the overall fraction of households receiving housing subsidies of either form in each MSA). Indeed, data from "A Picture of Subsidized Housing in the 1970s" (also made available by HUD) confirms that the number of in-kind public housing units used to provide housing assistance throughout U.S. cities in 1998 was essentially determined several decades ago. Specifically, over 87 percent of the public housing projects that existed in 1977 still existed and were in use in 1998. Moreover, very few public housing projects were built between the 1970s and 1998, with 62 percent of all public housing projects that existed and were in use in 1998 being constructed prior to 1977, and over 92 percent of those projects larger than 200 units being constructed prior to 1977. Overall, this evidence reveals that most of the current use of public housing project units was determined by decisions made in the 1970s or before, well prior to the large increases in crime that occurred in the 1980s or any of the decreases in crime that took place over the 1990s.

The second variable I use as an instrument for segregation by poverty status was first used by Cutler and Glaeser (1997) as an instrument for racial segregation—namely the share of local government revenue in an MSA that comes from the state or federal government in 1962. ${ }^{15}$ With more money coming from outside sources, there is less of an incentive for individuals within a city to segregate by income, since a smaller fraction of local public goods are funded through local taxes. Therefore, a greater fraction of local revenue coming from the state or federal government should lead to less economic segregation in an MSA. ${ }^{16}$

\footnotetext{
${ }^{15}$ This data comes from the Census of Governments 1962, made available by the Inter-University Consortium for Political and Social Research (ICPSR) website.

${ }^{16}$ Note that while Cutler and Glaeser (1997) motivate this instrument identically to here, they use theirs to instrument for racial segregation, under the further motivation that income and race are strongly correlated
} 
The first column of numbers in Table III shows the results of the first stage regression of the Poverty Isolation Index calculated using all census tracts on the two instruments meeting the exclusion restriction and the other MSA characteristics included in the original regressions from Table II. The second column of numbers in Table III shows the analogous results that arise when using the Poverty Isolation Index calculated using only census tracts made up of less than 60 percent students. As can be seen, the two instruments discussed above are significantly related to Poverty Isolation Index (using either calculation method) in the predicted manner. However, as should be expected, both the magnitude of the estimated coefficients on the excluded instruments, as well as the F-statistic for the joint significance of the two instruments, are larger when using the Poverty Isolation Index calculated using only census tracts made up of less than 60 percent students. ${ }^{17}$ Therefore, I will again focus on the results using this construction of the Poverty Isolation Index.

Table IV shows the results from the 2SLS specifications. The first column in Table IV reveals that, if anything, greater segregation by poverty status actually decreases rates of burglary. While not statistically significant at standard levels of significance (p-value 0.117), the coefficient is relatively large in magnitude, suggesting that a one standard deviation increase in the Poverty Isolation Index leads to a decrease in burglary rates by roughly twothirds of a standard deviation. ${ }^{18}$ Alternatively, the results shown in Table IV with respect to larceny and motor vehicle theft reveal little effect of segregation by poverty status on these crimes.

Finally, the most notable results are shown in the last two columns of Table IV, which suggest that greater segregation by poverty status leads to much higher rates of the violent interpersonal crimes of robbery and aggravated assault, with these effects being statistically significant at the 10 percent level or higher. The point estimates indicate that a one standard in the U.S.

${ }^{17}$ Indeed, the F-statistic on the joint significance of the instruments when using the Poverty Segregation Index calculated without the student heavy census tracts is arguably large enough to mitigate any concerns regarding weak instrument bias (Stock and Yogo, 2002).

${ }^{18}$ This translates to an almost 50 percent lower burglary rate (computed using the mean and standard deviation for burglaries from Table I). 
deviation increase in the Poverty Isolation Index is associated with an increase in robbery rates by roughly two-thirds of a standard deviation and almost nine-tenths of a standard deviation increase in the rate of aggravated assault. ${ }^{19}$

Table $\mathrm{V}$ shows that the above 2SLS results are robust to other measures of segregation. In particular, the top panel of Table $\mathrm{V}$ reveals the coefficients on different poverty segregation measures in otherwise analogous 2SLS specifications. The top row of numbers in Table V simply repeats the coefficients on the Poverty Segregation Index shown in the top row of Table IV. The remaining rows show the analogous coefficients when using several alternative construction methods for measures of segregation. Specification 1 uses the (standardized) Poverty Isolation Index calculated using all census tracts (including those made up of over 60 percent college students). Specification 2 uses the (standardized) Poverty Dissimilarity Index, which answers the question "what share of the poor population would need to change census tracts for the poor and non-poor to be evenly distributed within a city?" and is constructed using the formula $\frac{1}{2} \sum_{i=1}^{N}\left|\frac{\text { poor }_{i}}{\text { poor }_{\text {total }}}-\frac{\text { non-poor }_{i}}{\text { non-poor }_{\text {total }}}\right|$ for each MSA (Massey and Denton, 1988). Specification 3 uses the (standardized) Poverty Dissimilarity Index but constructed without using those census tracts made up of over 60 percent college students. Specification 4 once again uses the (standardized) Isolation Index computed using all census tracts, but adjusts for the overall fraction of the MSA that is poor (see Cutler and Glaeser, 1997). ${ }^{20}$ Specification 5 again uses this "adjusted" Poverty Isolation Index, but computes it excluding those census tracts made up of over 60 percent college students. One concern regarding

\footnotetext{
${ }^{19}$ Given the mean and standard deviation for robbery rates per 100 thousand residents are 133 and 85 respectively, the above estimates suggest that a one standard deviation increase in poverty segregation leads to a roughly 40 percent higher robbery rate, all else equal. Similarly, given the mean and standard deviation for aggravated assault rates are 321and 165 respectively, the above estimates suggest that a one standard deviation increase in poverty segregation leads to roughly 45 percent higher aggravated assault rate, all else equal.

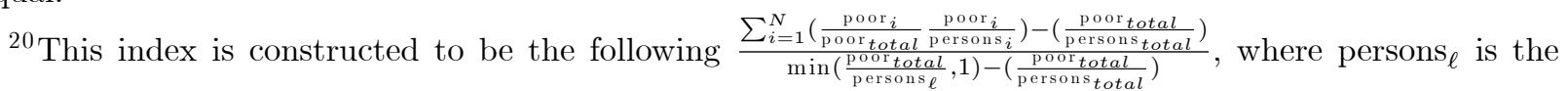
number of persons in the census tract with the lowest population with in the city and $i$ once again denotes census tract. The first term in the top part of the above equation is the fraction poor in the census tract occupied by the average poor individual. From this, we can subtract the percentage poor in the city as a whole to eliminate the effect coming from the overall size of the poor population. This whole term is then normalized to be between zero and one, with one indicating the city is the most segregated it can possibly be.
} 
all of these poverty segregation measures is that they treat the poor as being distinct from everyone else including the near poor, which obviously is not true. Therefore, Specification 6 again uses the Poverty Isolation Index calculated using all census tracts, but excludes those individuals in each census tract whose household earnings are above the poverty line but less than one and a half times the poverty line (the "near" poor), and Specification 7 uses the Poverty Isolation Index that both excludes those census tracts made up of over 60 percent students and excludes those individuals who are "near" poor. Finally, the lower panel of Table V shows the 2SLS coefficients on three different indices of racial segregation.

As Table V shows, the coefficients on the segregation index in the Burglary specifications are negative using all ten alternative indices and significantly so in nine of them with magnitudes both somewhat smaller and larger than the coefficients that arise using the preferred measure (i.e. top row). The coefficients on the poverty segregation indices in the Larceny and Motor Vehicle Theft specifications are negative using all ten alternative measures, but never even close to being statistically different from zero. Finally, the coefficients on the alternative poverty segregation indices in the Robbery and Aggravated Assault specifications are always positive and significantly so in eighteen of the twenty specifications, with magnitudes again both somewhat smaller and somewhat larger than those shown in the top row of Table $\mathrm{V}$.

In their paper on the consequences of ghettos, Cutler and Glaeser (1997) also use two further instruments for (racial) segregation beyond the fraction of local government revenue coming from the State or Federal governments - namely the number of local municipal governments in each MSA, and the number of rivers flowing through each MSA. ${ }^{21}$ I also estimated the 2SLS specifications using these variables as additional instruments for poverty segregation. However, as the top three rows of Table IV show, using these additional instruments leads to no substantive differences in the estimated results, but does dramatically

\footnotetext{
${ }^{21}$ There has been considerable debate on how this variable should be property measured (see Rothstein (2007) and Hoxby (2007)). Given it is not the focus of this analysis, I simply decided to use the number of "long" rivers flowing through each MSA as coded by Jesse Rothstein. Thanks to Jesse Rothstein for providing me with this data.
} 
lower the F-statistic on the joint significance of the excluded instruments in the first stage regression. The fact that these further instruments do not seem to add much power to the analysis is the reason why they were not included in the "preferred" specifications shown in Table IV. Moreover, the last row of Table VI shows the coefficients on the Poverty Isolation Index variable in the five 2SLS specifications using only the Cutler and Glaeser instruments (i.e. the fraction of local revenue received from state or federal sources, the number of municipal governments in each MSA, and the number of rivers in each MSA). These coefficients show that not using the "fraction of public housing given in-kind" instrument does alter the coefficients a good deal (especially those in the larceny and motor vehicle theft specifications), but the general conclusion remains that greater economic segregation appears to have differential effects on violent crimes versus basic property crimes.

\subsection{Discussion of Empirical Results}

Clearly, the validity of the 2SLS results presented above rest on the validity of the proposed instruments. On the most basic level, Table III (and the last column of Table V) showed that both of the primary instruments argued to meet the exclusion restriction are indeed significantly correlated with segregation in the predicted manner. Therefore, one criteria for the validity of the instruments seems to be met. Moreover, given we have more excluded instruments than potentially endogenous variables, the model is overidentified, which means we can directly test whether it is inappropriate to exclude the instruments discussed above from being related to crime in 2000 other than through segregation (Wooldridge, 2002). The instruments pass this test. In particular, the p-value on the Sargan statistics for the specifications in Table IV range from 0.13 (Motor Vehicle Theft) to 0.81 (Robbery).

Another potential test of the validity of these instruments is to see if they have a significant relationship to other key metro area characteristics, such as the poverty rate or the poverty rate for blacks, after controlling for segregation by poverty status, as well as the

other metro area characteristics. If they do, this suggests that these proposed instrumental 
variables may directly influence a variety of characteristics of a city in addition to segregation, which may then have their own direct affects on crime. ${ }^{22}$ However, running similar first stage regressions to those shown in Table III, but using "percent living in poverty" as the dependant variable and adding the Poverty Isolation Index to the right-hand side variables, the coefficients on the two excluded instruments are small in magnitude and statistically insignificant at any standard level of significance. Similarly, when I regress "percent of blacks living in poverty" on the instruments, any of the segregation indices, and the remaining right-hand side variables, the coefficients on the two instruments are again small and statistically insignificant. In other words, other than through their relationship to segregation, the two instruments do not appear to be related to poverty rates as a whole or poverty rates for blacks. Moreover, when I do the analogous exercise with "percent of households headed by single mother" as the dependant variable I again get coefficients that are small in magnitude on both instruments, but while small in magnitude, the coefficient on the public housing instrument is significantly negative at the $5 \%$ level. In other words, if anything, after controlling for all of the other metro area characteristics, a higher fraction of public housing given in-kind leads to lower rates of single parent headed households. Therefore, the above tests are consistent (though admittedly not conclusive) with the notion that instruments are not simply picking up the effects of some omitted variable that affects both current crimes rates and the composition of public housing subsidies and/or the historical sources of local revenue.

Perhaps the strongest evidence that mitigates concerns regarding the invalidity of the proposed instruments are the differential findings across crime types in the 2SLS specifications. In particular, if the instruments were strongly related to unmeasured variables affecting opportunities for the poor and/or black residents, such as social services availability and schooling, we should expect the 2SLS results to be similar across crime types, or even more strongly positive for basic property crimes. Intuitively, if the instruments are directly

\footnotetext{
${ }^{22}$ Thanks to Francisco Martorell for suggesting this.
} 
related to some omitted variable measuring relative depravation or lack of opportunities for the poor and/or blacks, such relative deprivation should impact basic property crime behavior in similar ways to violent crime behavior. However, the 2SLS results discussed above contradict this, and instead reveal that these instruments appear to have a negative or negligible relationship with basic property crimes, but a strong positive relationship to violent crimes.

Finally, it is also interesting to consider the differences in the empirical results across the different basic property crime categories within the context of the model. For example, the empirical results suggested that greater economic segregation has an arguably negative impact on burglary rates. In the context of the model, this suggests that an individual's payoff to burglary depends on the economic characteristics of his neighbors. This would be true if burglars focused their crimes on the other residents of their neighborhoods. This seems plausible, as a person would generally only break and enter a residence or commercial establishment if he had knowledge of something valuable to steal. Clearly, such information would be better locally than more distantly. On the other hand, the empirical results suggested that greater segregation had no impact on larceny and motor vehicle theft. In the context of the model this would suggest an individual's payoff to these crimes does not depend on the economic characteristics of his neighbors. Given larceny and motor vehicle theft generally involve taking readily observable items, perpetrators of such crimes can easily travel to other neighborhoods to commit such crimes, suggesting it to be reasonable that the payoff to such crimes has little relationship to his own neighbor's characteristics.

\section{Conclusion}

The model developed in this paper showed that a very standard behavioral assumption, namely that individuals incur diminishing marginal utility of money, can have substantial implications when it comes to criminal participation. In particular, the model not only 
showed how such an assumption can cause poverty to affect an individual's likelihood of engaging in all types of crime, but also tha "neighborhood effects" can actually arise under very minimal additional assumptions, particularly when it comes to violent crime.

Importantly, the model also showed that the diminishing marginal utility of money assumption will mean that this neighborhood effect will be stronger for poor individuals than non-poor individuals, or in other words, that violent criminal behavior of poor individuals may be more influenced by neighborhood economic characteristics than is the violent criminal behavior of non-poor individuals. This in turn was shown to imply that while greater economic segregation might have no effect or potentially even a negative effect on the overall amount of basic property crime, it may be expected to lead to a higher level of violence than would occur if the poor were more evenly dispersed throughout the city.

While this implication was shown to be consistent with several empirical findings, certainly more evidence is necessary to definitively conclude that this model provides an important component regarding the connections between crime and poverty. However, if true, this theoretical model leads to a very important conclusion. Namely, that when it comes to violent crime, not only do an individual's own economic characteristics matter, but so do the economic characteristics of his neighbors. Therefore, while it is clear that policies dictating how public housing is allocated and how an urban area is developed will affect who is victimized by crime, such policies may also have a significant impact on who commits crime and the overall amount of crime that occurs. Moreover, the results of this paper suggest that demolition and decreased use of large housing projects over the last decade may be an important component in declining rates of violence over the last decade.

\section{References}

[1] Anderson, Elijah. (1999). Code of the Street: Decency, Violence and the Moral Life of the Inner City. New York: W.W. Norton and Company. 
[2] Bayer, Patrick, Robert McMillan, and Kim Rueben. (2004). "What Drives Racial Segregation? New Evidence Using Census Microdata." Journal of Urban Economics 56(3): 574-35.

[3] Brock, William and Steven Durlauf. (2001). "Discrete Choice with Social Interactions," Review of Economic Studies 68(2): 235-260.

[4] Calvo-Armengol, Antoni and Yves Zenou. (2004). "Social Networks and Crime Decisions: The Role of Social Structure in Facilitating Delinquent Behavior," International Economic Review 45(3): 939-958.

[5] Calvo-Armengol, Thierry Verdier, and Antoni and Yves Zenou. (2007). "Strong Ties and Weak Ties in Employment and Crime." Journal of Public Economics 91: 203-233.

[6] Cullen, Julie Berry and Steven D. Levitt. (1999). "Crime, Urban Flight, and the Consequences for Cities," Review of Economics and Statistics 81(2): 159-69.

[7] Cutler, David, and Edward Glaeser. (1997). “Are Ghettos Good or Bad?" Quarterly Journal of Economics 112(3): 827-72.

[8] Cutler, David, Edward Glaeser, and Jacob Vigdor. (1999). "The Rise and Decline of the American Ghetto," Journal of Political Economy 107(3): 455-506.

[9] Duncan, Otis Dudley and Beverly Duncan. (1955). "A Methodological Analysis of Segregation indices," American Sociological Review 20(2): 210-17.

[10] Federal Bureau of Investigation. (2000). "Crime in the United States 2000, Uniform Crime Reports," U.S. Department of Justice, Washington D.C.

[11] Ferrer, Rosa. (2008). "Breaking the law when others do: A model of law enforcement with neighborhood externalities." Working Paper.

[12] Glaeser, Edward, Bruce Sacerdote, and Jose Scheinkman. (1996). "Crime and Social Interactions," Quarterly Journal of Economics 111: 507-548. 
[13] Heavner, Lee and Lance Lochner. (2002). "Social Networks and the Aggregation of Individual Decision.” Working Paper, University of Western Ontario Department of Economics.

[14] Hoxby, Caroline. (2007). "Does Competition Among Public Schools Benefit Students and Taxpayers? Reply." American Economic Review 97(5): 2026-2037.

[15] Jacob, Brian, Lars Lefgren, and Enrico Moretti. (2007). "Dynamics of Criminal Behavior; Evidence from Weather Shocks." Journal of Human Resources 42(3): 489-527.

[16] Jankowski, Martin S. (1991). Islands in the Street: Gangs and American Urban Society. Berkeley: Unversity of California Press.

[17] Kling, Jeffrey, Jens Ludwig, and Lawrence Katz. (2005). "Neighborhood Effects on Crime for Female and Male Youth: Evidence from a Randomized Housing Voucher Experiment," Quarterly Journal of Economics 120(1).

[18] Kotlowitz, Alex, (1991). There are No Children Here, New York: Random House Inc.

[19] Krivo, Lauren and Ruth D. Peterson. (1996). "Extremely Disadvantaged Neighborhoods and Urban Crime," Social Forces 75(2): 619-650.

[20] Landesman, Peter. (2007). "Nine Miles and Spreading." LA Weekly, December 14-20: 44-51.

[21] Logan, J.R. and S. Messner (1987). "Racial Residential Segregation and Suburban Violent Crime." Social Science Quarterly 68: 510-527.

[22] Massey, Douglas S. (1995). "Getting Away with Murder: Segregation and Violent Crme in Urban America." University of Pennsylvania Law Review 143(5): 1203-1232.

[23] Massey, Douglas S. and Nancy Denton. (1988). "Suburbanization and Segregation in U.S. Metropolitan Areas, " American Journal of Sociology 94(3): 592-626. 
[24] Messner, Steven F. and Kenneth Tardiff. (1986). "Economic Inequality and Levels of Homicide: An Analysis of Urban Neighborhoods. " Criminology 24: 297-317.

[25] Murray, Michael P. (2006). "Avoiding Invalid Instruments and Coping with Weak Instruments." Journal of Economic Perspectives 20(4): 111-132.

[26] O'Flaherty, Brenden and Rajiv Sethi. (2007). "Crime and Segregation." Journal of Economic Behavior and Organization 64: 391-405.

[27] Patacchini, Eleonora and Yves Zenou. (2008). "The Strength of Weak Ties in Crime." European Economic Review 52: 209-236.

[28] Patterson, E. Britt. (1991). "Poverty, Income Inquality, and Community Crime Rates," Criminology 29: 755-76.

[29] Rothstein, Jesse. (2007). "Does Competition Among Public Schools Benefit Students and Taxpayers? A Comment on Hoxby (2000).” American Economic Review 97(5): 2026-2037.

[30] Sampson, R.J. (1985). "Race and Criminal Violence: A Demographically Disaggregated Analysis of Urban Homicide." Crime and Delinquency 31:47-82.

[31] Savitz, Leonard D., Lawrence Rosen, and Michael Lalli. (1980). "Delinquency and Gang Membership as Related to Victimization." Victimology 5(2-4):152-60.

[32] Sethi, Rajiv and Rohini Somanathan. (2004). "Inequality and Segregation." Journal of Political Economy 112(6): 1296-1321.

[33] Shihadeh, Edward and Nicole Flynn. (1996). "Segregation and Crime: The Effect of Black Isolation on the Rates of Black Urban Violence." Social Forces 74(4): 1325-1352.

[34] Shihadeh, Edward and Micheal Maume. (1997). "Segregation and Crime: The Relationship Between Black Centralization and Urban Black Homicide.” Homicide Studies 1(3): 254-280. 
[35] Silverman, Dan. (2004). "Street Crime and Street Culture," International Economic Review 45(3): 761-786.

[36] Spergel, Irving A. (1990). "Youth Gangs: Continuity and Change." Crime and Justice 12: $171-275$.

[37] Stock, James and Motohiro Yogo. (2002). "Testing for Weak Instruments in Linear IV Regression." NBER Technical Working Paper 284.

[38] Taeuber, Karl E., Alma F. Taeuber (1965). Negroes in Cities: Residential Segregation and Neighborhood Change. Chicago: Aldine.

[39] Tiebout, Charles. (1956). "A Pure Theory of Local Expenditures," Journal of Political Economy 64(5): 416-24.

[40] U.S. Dept. of Justice, Federal Bureau of Investigation. (2002). UNIFORM CRIME REPORTING PROGRAM DATA [UNITED STATES]: COUNTY-LEVEL DETAILED ARREST AND OFFENSE DATA, 2000 [Computer file]. 3rd ICPSR ed. Ann Arbor, MI: Inter-university Consortium for Political and Social Research [producer and distributor].

[41] Verdier, Thierry and Yves Zenou. (2004). "Racial Beliefs, Location, and the Causes of Crime," International Economic Review 45(3): 731-760.

[42] Wilson, William Julius. (1987). The Truly Disadvantaged. Chicago: University of Chicago Press.

[43] Wooldridge, Jeffrey W. (2002). Econometric Analysis of Cross Section and Panel Data. Cambridge MA: MIT Press. 


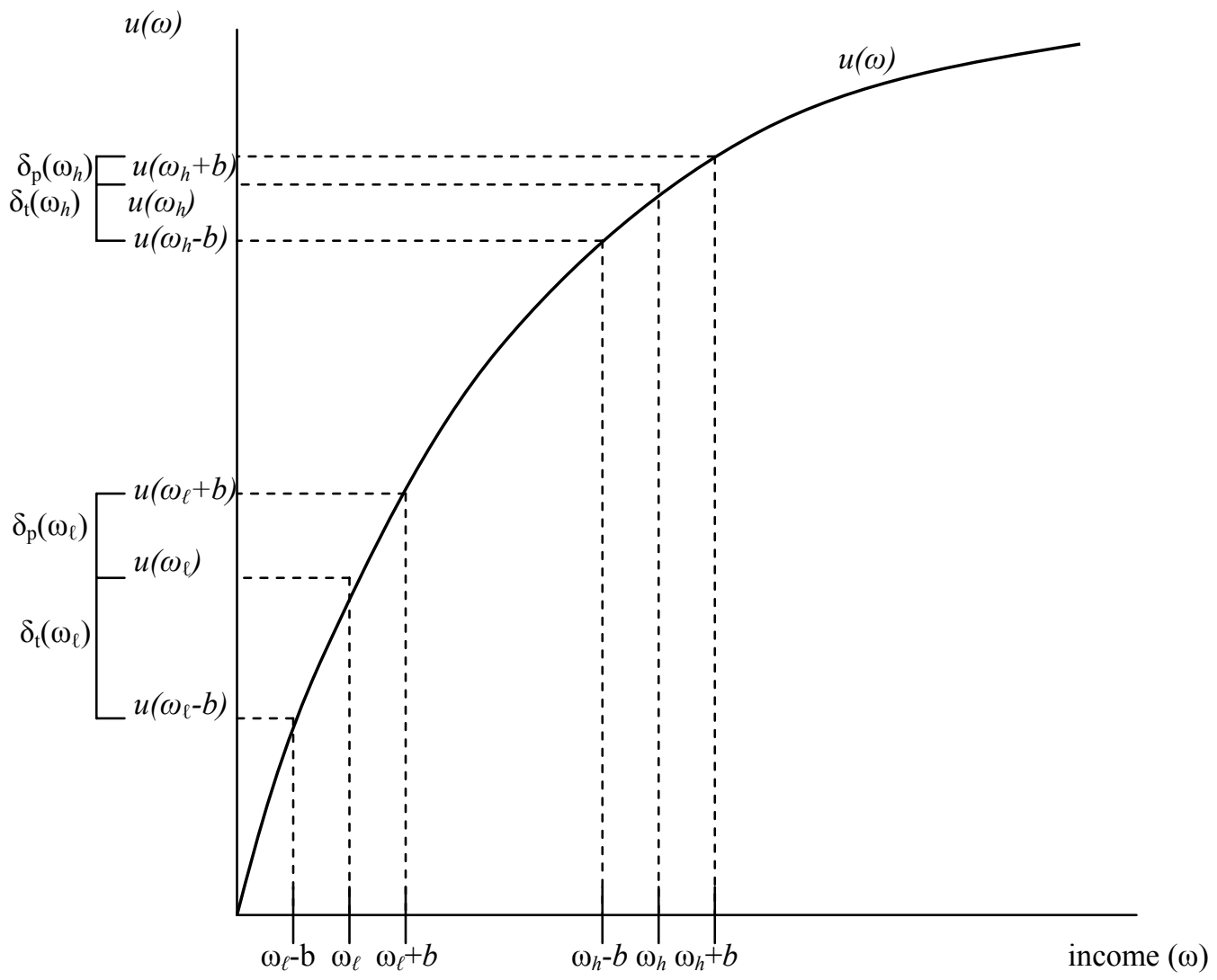

Figure 1 - Graphical depiction showing that $\delta_{t}\left(\omega_{\ell}\right)>\delta_{p}\left(\omega_{\ell}\right)>\delta_{t}\left(\omega_{h}\right)>\delta_{p}\left(\omega_{h}\right)$ will be true with strictly concave $u$ function. 
Table I - Descriptive Statistics of Data

\begin{tabular}{|c|c|c|}
\hline Variable & Mean & Std. Dev. \\
\hline \multicolumn{3}{|l|}{ Crime } \\
\hline \multicolumn{3}{|l|}{ Basic Property Crimes (in 2000) } \\
\hline burglaries per $100 \mathrm{~K}$ residents & 836 & 323 \\
\hline larcenies per $100 \mathrm{~K}$ residents & 2903 & 944 \\
\hline motor vehicle thefts per $100 \mathrm{~K}$ residents & 388 & 210 \\
\hline \multicolumn{3}{|l|}{ Interpersonal Crimes (in 2000) } \\
\hline robberies per $100 \mathrm{~K}$ residents & 133 & 85 \\
\hline aggravated assaults per $100 \mathrm{~K}$ residents & 321 & 165 \\
\hline law enforcement officers per 1000 residents & 244 & 150 \\
\hline \multicolumn{3}{|l|}{ MSA Characteristics } \\
\hline total population & 893,239 & $1,298,606$ \\
\hline percent poor & 12.3 & 4.5 \\
\hline percent urban & 82.0 & 11.1 \\
\hline percent immigrant & 1.2 & 0.9 \\
\hline percent black & 11.0 & 9.9 \\
\hline percent hispanic & 11.5 & 15.8 \\
\hline percent of adults with college degree & 23.9 & 6.8 \\
\hline percent of households headed by single mother & 7.5 & 1.6 \\
\hline percent of households receiveing housing assistance & 2.1 & 1.0 \\
\hline unemployment rate & 5.9 & 1.9 \\
\hline percent of days over 100 degrees & 11.1 & 8.0 \\
\hline percent of days below 32 degrees & 22.2 & 13.4 \\
\hline \multicolumn{3}{|l|}{ Segregation } \\
\hline Isolation Index of Segregation by Poverty Status & 0.20 & 0.06 \\
\hline $\begin{array}{l}\text { Isolation Index of Segregation by Poverty Status } \\
\text { (excluding tracts with over } 60 \% \text { of population in college) }\end{array}$ & 0.19 & 0.05 \\
\hline Isolation Index of Segregation by Race & 0.33 & 0.07 \\
\hline Number of observations & 228 & \\
\hline
\end{tabular}


Table II - OLS Regession Results

\begin{tabular}{|c|c|c|c|c|c|}
\hline \multirow[b]{2}{*}{ Variable } & \multicolumn{5}{|c|}{ Dependant Variable } \\
\hline & $\begin{array}{l}\text { standardized } \\
\text { burglary rate }\end{array}$ & $\begin{array}{l}\text { standardized } \\
\text { larceny rate }\end{array}$ & $\begin{array}{c}\text { standardized } \\
\text { motor vehicle } \\
\text { theft rate }\end{array}$ & $\begin{array}{l}\text { standardized } \\
\text { robbery rate }\end{array}$ & $\begin{array}{c}\text { standardized } \\
\text { aggravated } \\
\text { assault rate }\end{array}$ \\
\hline \multirow{2}{*}{$\begin{array}{l}\text { std. poverty isolation index } \\
\text { (excluding tracts with over } 60 \% \text { in college) }\end{array}$} & 0.078 & 0.075 & 0.240 & 0.346 & 0.213 \\
\hline & $(0.125)$ & $(0.137)$ & $(0.123)^{*}$ & $(0.106)^{* * *}$ & $(0.129)$ \\
\hline \multirow[t]{2}{*}{ Officers per 1000 residents 1999} & 0.109 & 0.055 & 0.014 & 0.107 & 0.098 \\
\hline & $(0.037)^{* * *}$ & $(0.040)$ & $(0.036)$ & $(0.031)^{* * *}$ & $(0.038)^{* * *}$ \\
\hline \multirow[t]{2}{*}{ percent in poverty } & 0.052 & 0.063 & -0.027 & -0.059 & -0.005 \\
\hline & $(0.039)$ & $(0.043)$ & $(0.038)$ & $(0.033)^{*}$ & $(0.040)$ \\
\hline \multirow[t]{2}{*}{ log of population } & -0.131 & -0.252 & 0.373 & 0.310 & 0.162 \\
\hline & $(0.074)^{*}$ & $(0.081)^{* * *}$ & $(0.073)^{* * *}$ & $(0.063)^{* * *}$ & $(0.076)^{* *}$ \\
\hline \multirow[t]{2}{*}{ percent urban } & 0.017 & 0.018 & 0.027 & 0.018 & 0.003 \\
\hline & $(0.007)^{* *}$ & $(0.008)^{* *}$ & $(0.007)^{* * *}$ & $(0.006)^{* * *}$ & $(0.008)$ \\
\hline \multirow[t]{2}{*}{ percent immigrant } & -0.072 & -0.053 & -0.096 & -0.023 & -0.023 \\
\hline & $(0.064)$ & $(0.070)$ & $(0.063)$ & $(0.054)$ & $(0.066)$ \\
\hline \multirow[t]{2}{*}{ percent black } & 0.009 & -0.014 & -0.001 & 0.039 & -0.010 \\
\hline & $(0.012)$ & $(0.013)$ & $(0.011)$ & $(0.010)^{* * *}$ & $(0.012)$ \\
\hline \multirow[t]{2}{*}{ percent hispanic } & -0.015 & -0.013 & -0.015 & 0.001 & -0.004 \\
\hline & $(0.007)^{* *}$ & $(0.007)^{*}$ & $(0.006)^{* *}$ & $(0.006)$ & $(0.007)$ \\
\hline \multirow[t]{2}{*}{ percent with college degree } & -0.025 & 0.005 & -0.011 & -0.018 & -0.016 \\
\hline & $(0.010)^{* * *}$ & $(0.011)$ & $(0.010)$ & $(0.008)^{* *}$ & $(0.010)$ \\
\hline \multirow[t]{2}{*}{ percent of $\mathrm{HH}$ with single mother } & 0.088 & 0.213 & 0.171 & -0.007 & 0.110 \\
\hline & $(0.064)$ & $(0.070)^{* * *}$ & $(0.063)^{* * *}$ & $(0.054)$ & $(0.066)^{*}$ \\
\hline \multirow[t]{2}{*}{ percent of HH subsidized } & -0.120 & -0.010 & -0.105 & 0.036 & -0.078 \\
\hline & $(0.061)^{*}$ & $(0.067)$ & $(0.060)^{*}$ & $(0.052)$ & $(0.063)$ \\
\hline \multirow[t]{2}{*}{ percent unemployed } & -0.029 & -0.124 & 0.066 & 0.012 & -0.011 \\
\hline & $(0.054)$ & $(0.059)^{* *}$ & $(0.053)$ & $(0.046)$ & $(0.056)$ \\
\hline \multirow[t]{2}{*}{ percent of days above $90 \mathrm{deg}}$. & 0.100 & 0.114 & 0.066 & 0.070 & 0.118 \\
\hline & $(0.032)^{* * *}$ & $(0.034)^{* * *}$ & $(0.031)^{* *}$ & $(0.027)^{* * *}$ & $(0.032)^{* * *}$ \\
\hline \multirow[t]{2}{*}{ sq. of percent of days above 90} & -0.002 & -0.002 & -0.001 & -0.002 & -0.003 \\
\hline & $(0.001)^{* *}$ & $(0.001)^{*}$ & $(0.001)$ & $(0.001)^{* * *}$ & $(0.001)^{* * *}$ \\
\hline \multirow[t]{2}{*}{ percent of days below $32 \mathrm{deg}$. } & 0.025 & 0.059 & 0.019 & 0.029 & -0.049 \\
\hline & $(0.017)$ & $(0.019)^{* * *}$ & $(0.017)$ & $(0.014)^{* *}$ & $(0.017)^{* * *}$ \\
\hline \multirow[t]{2}{*}{ sq. of percent of days below 32} & -0.000 & -0.001 & -0.000 & -0.000 & 0.001 \\
\hline & $(0.000)$ & $(0.000)^{* *}$ & $(0.000)$ & $(0.000)^{*}$ & $(0.000)^{* *}$ \\
\hline $\mathrm{N}$ & 228 & 228 & 228 & 228 & 228 \\
\hline $\mathrm{R}$ - square & 0.40 & 0.38 & 0.51 & 0.63 & 0.38 \\
\hline
\end{tabular}

Standard errors in parentheses. * significant at 10\%; ** significant at 5\%; *** significant at $1 \%$. 


\begin{tabular}{|c|c|c|}
\hline \multirow[b]{2}{*}{ Control Variables } & \multicolumn{2}{|c|}{ Dependant Variable } \\
\hline & $\begin{array}{c}\text { std. poverty } \\
\text { isolation index }\end{array}$ & $\begin{array}{c}\text { std. poverty } \\
\text { isolation index } \\
\text { (excluding census tracts } \\
\text { with over } 60 \% \text { in college) }\end{array}$ \\
\hline \multicolumn{3}{|c|}{ INSTRUMENTS MEETING EXCLUSION RESTRICTION } \\
\hline \multirow[t]{2}{*}{ percent of housing assistance via public housing } & 0.003 & 0.004 \\
\hline & $(0.002)^{* *}$ & $(0.001)^{* * *}$ \\
\hline \multirow{2}{*}{ percent of local rev. coming from State \& Fed gov't. } & -0.009 & -0.010 \\
\hline & $(0.003)^{* * *}$ & $(0.003)^{* * *}$ \\
\hline \multicolumn{3}{|l|}{ NON-EXCLUDED } \\
\hline \multirow[t]{2}{*}{ officers per 1000 residents 1999} & -0.012 & 0.009 \\
\hline & $(0.000)$ & $(0.000)$ \\
\hline \multirow[t]{2}{*}{ percent in poverty } & 0.245 & 0.213 \\
\hline & $(0.016)^{* * *}$ & $(0.014)^{* * *}$ \\
\hline \multirow[t]{2}{*}{ log of population } & 0.037 & 0.122 \\
\hline & $(0.042)$ & $(0.038)^{* * *}$ \\
\hline \multirow[t]{2}{*}{ percent urban } & 0.012 & 0.010 \\
\hline & $(0.004)^{* * *}$ & $(0.004) * *$ \\
\hline \multirow[t]{2}{*}{ percent immigrant } & -0.077 & -0.077 \\
\hline & $(0.037)^{* *}$ & $(0.034)^{* *}$ \\
\hline \multirow[t]{2}{*}{ percent black } & 0.023 & 0.021 \\
\hline & $(0.007)^{* * *}$ & $(0.006) * * *$ \\
\hline \multirow[t]{2}{*}{ percent hispanic } & -0.006 & -0.000 \\
\hline & $(0.004)$ & $(0.003)$ \\
\hline \multirow[t]{2}{*}{ percent with college degree } & 0.027 & 0.001 \\
\hline & $(0.006)^{* * *}$ & $(0.005)$ \\
\hline \multirow[t]{2}{*}{ percent of $\mathrm{HH}$ with single mother } & -0.008 & 0.060 \\
\hline & $(0.037)$ & $(0.034)^{*}$ \\
\hline \multirow[t]{2}{*}{ percent of households subsidized } & -0.113 & -0.068 \\
\hline & $(0.035)^{* * *}$ & $(0.032)^{* *}$ \\
\hline \multirow[t]{2}{*}{ unemployment rate } & -0.043 & -0.031 \\
\hline & $(0.031)$ & $(0.028)$ \\
\hline \multirow[t]{2}{*}{ percent of days above 90 deg. } & -0.050 & -0.038 \\
\hline & $(0.018)^{* * *}$ & $(0.016)^{* *}$ \\
\hline \multirow[t]{2}{*}{ sq. of percent of days above 90} & 0.001 & 0.001 \\
\hline & $(0.001)^{* *}$ & $(0.001)^{* *}$ \\
\hline \multirow[t]{2}{*}{ percent of days below 32 deg. } & 0.012 & 0.011 \\
\hline & $(0.010)$ & $(0.009)$ \\
\hline \multirow[t]{2}{*}{ sq. of percent of days below 32} & -0.000 & -0.000 \\
\hline & $(0.000)$ & $(0.000)$ \\
\hline \multirow[t]{2}{*}{ constant } & -4.304 & -5.073 \\
\hline & $(0.605)^{* * *}$ & $(0.552)^{* * *}$ \\
\hline $\mathrm{N}$ & 228 & 228 \\
\hline $\mathrm{R}$ - square & 0.82 & 0.86 \\
\hline F-stat for excluded instruments & $6.72^{* *}$ & $10.69 * * *$ \\
\hline
\end{tabular}


Table IV - 2SLS Regession Results

\begin{tabular}{|c|c|c|c|c|c|}
\hline \multirow[b]{2}{*}{ Variable } & \multicolumn{5}{|c|}{ Dependant Variable } \\
\hline & $\begin{array}{l}\text { standardized } \\
\text { burglary rate }\end{array}$ & $\begin{array}{l}\text { standardized } \\
\text { larceny rate }\end{array}$ & $\begin{array}{c}\text { standardized } \\
\text { motor vehicle } \\
\text { theft rate }\end{array}$ & $\begin{array}{l}\text { standardized } \\
\text { robbery rate }\end{array}$ & $\begin{array}{c}\text { standardized } \\
\text { aggravated } \\
\text { assault rate }\end{array}$ \\
\hline \multirow{2}{*}{$\begin{array}{l}\text { std. poverty isolation index } \\
\text { (excluding tracts with over } 60 \% \text { in college) }\end{array}$} & -0.672 & -0.053 & 0.002 & 0.643 & 0.886 \\
\hline & $(0.429)$ & $(0.434)$ & $(0.394)$ & $(0.343)^{*}$ & $(0.433)^{* *}$ \\
\hline \multirow[t]{2}{*}{ officers per 1000 residents in 1999} & 0.132 & 0.059 & 0.022 & 0.100 & 0.077 \\
\hline & $(0.040)^{* * *}$ & $(0.041)$ & $(0.037)$ & $(0.032)^{* * *}$ & $(0.041)^{*}$ \\
\hline \multirow[t]{2}{*}{ percent in poverty } & 0.220 & 0.092 & 0.026 & -0.126 & -0.156 \\
\hline & $(0.100)^{* *}$ & $(0.101)$ & $(0.092)$ & $(0.080)$ & $(0.101)$ \\
\hline \multirow[t]{2}{*}{ log of population } & -0.029 & -0.235 & 0.405 & 0.270 & 0.071 \\
\hline & $(0.095)$ & $(0.096)^{* *}$ & $(0.087)^{* * *}$ & $(0.076)^{* * *}$ & $(0.096)$ \\
\hline \multirow[t]{2}{*}{ percent urban } & 0.027 & 0.020 & 0.030 & 0.015 & -0.006 \\
\hline & $(0.009)^{* * *}$ & $(0.009)^{* *}$ & $(0.009)^{* * *}$ & $(0.007)^{* *}$ & $(0.009)$ \\
\hline \multirow[t]{2}{*}{ percent immigrant } & -0.109 & -0.059 & -0.108 & -0.008 & 0.010 \\
\hline & $(0.070)$ & $(0.070)$ & $(0.064)^{*}$ & $(0.056)$ & $(0.070)$ \\
\hline \multirow[t]{2}{*}{ percent black } & 0.026 & -0.011 & 0.004 & 0.032 & -0.025 \\
\hline & $(0.015)^{*}$ & $(0.015)$ & $(0.014)$ & $(0.012)^{* * *}$ & $(0.015)^{*}$ \\
\hline \multirow[t]{2}{*}{ percent hispanic } & -0.016 & -0.013 & -0.016 & 0.001 & -0.003 \\
\hline & $(0.007)^{* *}$ & $(0.007)^{*}$ & $(0.006)^{* *}$ & $(0.005)$ & $(0.007)$ \\
\hline \multirow[t]{2}{*}{ percent with college degree } & -0.030 & 0.004 & -0.012 & -0.016 & -0.012 \\
\hline & $(0.010)^{* * *}$ & $(0.011)$ & $(0.010)$ & $(0.008)^{* *}$ & $(0.011)$ \\
\hline \multirow[t]{2}{*}{ percent of $\mathrm{HH}$ with single mother } & 0.114 & 0.217 & 0.179 & -0.017 & 0.087 \\
\hline & $(0.068)^{*}$ & $(0.069)^{* * *}$ & $(0.063)^{* * *}$ & $(0.055)$ & $(0.069)$ \\
\hline \multirow[t]{2}{*}{ percent of HH subsidized } & -0.175 & -0.020 & -0.122 & 0.058 & -0.029 \\
\hline & $(0.070)^{* *}$ & $(0.071)$ & $(0.065)^{*}$ & $(0.056)$ & $(0.071)$ \\
\hline \multirow[t]{2}{*}{ unemployment rate } & -0.060 & -0.129 & 0.056 & 0.024 & 0.017 \\
\hline & $(0.059)$ & $(0.059)^{* *}$ & $(0.054)$ & $(0.047)$ & $(0.059)$ \\
\hline \multirow[t]{2}{*}{ percent of days above 90 deg. } & 0.063 & 0.107 & 0.054 & 0.084 & 0.151 \\
\hline & $(0.038)^{*}$ & $(0.039)^{* * *}$ & $(0.035)$ & $(0.031)^{* * *}$ & $(0.039)^{* * *}$ \\
\hline \multirow[t]{2}{*}{ sq. of percent of days above 90} & -0.001 & -0.002 & -0.001 & -0.003 & -0.004 \\
\hline & $(0.001)$ & $(0.001)$ & $(0.001)$ & $(0.001)^{* * *}$ & $(0.001)^{* * *}$ \\
\hline \multirow[t]{2}{*}{ percent of days below $32 \mathrm{deg}$. } & 0.035 & 0.060 & 0.022 & 0.025 & -0.058 \\
\hline & $(0.018)^{*}$ & $(0.019)^{* * *}$ & $(0.017)$ & $(0.015)^{*}$ & $(0.019)^{* * *}$ \\
\hline \multirow[t]{2}{*}{ sq. of percent of days below 32} & -0.001 & -0.001 & -0.000 & -0.000 & 0.001 \\
\hline & $(0.000)^{*}$ & $(0.000)^{* *}$ & $(0.000)$ & $(0.000)^{*}$ & $(0.000)^{* * *}$ \\
\hline \multirow[t]{2}{*}{ constant } & -4.961 & -1.917 & -9.484 & -4.093 & 0.979 \\
\hline & $(2.549)^{*}$ & $(2.576)$ & $(2.338) * * *$ & $(2.036)^{* *}$ & $(2.573)$ \\
\hline$\overline{\mathrm{N}}$ & 228 & 228 & 228 & 228 & 228 \\
\hline F-stat on excl. instruments & $10.69 * * *$ & $10.69 * * *$ & $10.69 * * *$ & $10.69^{* * *}$ & $10.69^{* * *}$ \\
\hline p-val on Sargan Stat. & 0.23 & 0.39 & 0.13 & 0.81 & 0.20 \\
\hline
\end{tabular}

Standard errors in parentheses. * significant at $10 \%$; ${ }^{* *}$ significant at $5 \%$; *** significant at $1 \%$. 
Table V - 2SLS Regession Coefficients on Alternative Segregation Indices

\begin{tabular}{|c|c|c|c|c|c|c|}
\hline \multirow[b]{2}{*}{ Measure of Segregation } & \multicolumn{5}{|c|}{ Dependant Variable } & \multirow[b]{2}{*}{$\begin{array}{l}\text { F-stat } \\
\text { on instr. }\end{array}$} \\
\hline & $\begin{array}{l}\text { standardized } \\
\text { burglary rate }\end{array}$ & $\begin{array}{c}\text { standardized } \\
\text { larceny rate }\end{array}$ & $\begin{array}{c}\text { standardized } \\
\text { motor vehicle } \\
\text { theft rate }\end{array}$ & $\begin{array}{l}\text { standardized } \\
\text { robbery rate }\end{array}$ & $\begin{array}{l}\text { standardized } \\
\text { d aggravated } \\
\text { e assault rate }\end{array}$ & \\
\hline $\begin{array}{l}\text { std. poverty isolation index } \\
\text { (excluding tracts with over } 60 \% \text { in college) }\end{array}$ & $\begin{array}{l}-0.672 \\
(0.429)\end{array}$ & $\begin{array}{l}-0.053 \\
(0.434)\end{array}$ & $\begin{array}{c}0.002 \\
(0.394)\end{array}$ & $\begin{array}{c}0.643 \\
(0.343)^{*}\end{array}$ & $\begin{array}{c}0.886 \\
(0.433)^{* *}\end{array}$ & $10.69 * * *$ \\
\hline \multicolumn{7}{|l|}{ Alternative Poverty Segregation Indices } \\
\hline $\begin{array}{l}1 \text { - std. poverty isolation index } \\
\text { (using all census tracts) }\end{array}$ & $\begin{array}{c}-0.840 \\
(0.503)^{*}\end{array}$ & $\begin{array}{c}-0.185 \\
(0.502)\end{array}$ & $\begin{array}{c}-0.082 \\
(0.455)\end{array}$ & $\begin{array}{c}0.746 \\
(0.419)^{*}\end{array}$ & $\begin{array}{c}0.936 \\
(0.527)^{*}\end{array}$ & $6.72 * *$ \\
\hline $\begin{array}{l}2 \text { - std. poverty dissimilarity index } \\
\text { (using all census tracts) }\end{array}$ & $\begin{array}{c}-0.541 \\
(0.302)^{*}\end{array}$ & $\begin{array}{l}-0.216 \\
(0.302)\end{array}$ & $\begin{array}{l}-0.122 \\
(0.271)\end{array}$ & $\begin{array}{c}0.433 \\
(0.241)^{*}\end{array}$ & $\begin{array}{c}0.461 \\
(0.297)\end{array}$ & $8.18^{* * *}$ \\
\hline $\begin{array}{l}3 \text { - std. poverty dissimilarity index } \\
\text { (excluding tracts with over } 60 \% \text { in college) }\end{array}$ & $\begin{array}{c}-0.509 \\
(0.287)^{*}\end{array}$ & $\begin{array}{l}-0.193 \\
(0.286)\end{array}$ & $\begin{array}{l}-0.107 \\
(0.258)\end{array}$ & $\begin{array}{c}0.413 \\
(0.225)^{*}\end{array}$ & $\begin{array}{c}0.449 \\
(0.279)\end{array}$ & $9.11^{* * *}$ \\
\hline $\begin{array}{l}4 \text { - std. "adjusted" poverty isolation index } \\
\text { (using all census tracts) }\end{array}$ & $\begin{array}{c}-0.501 \\
(0.295)^{*}\end{array}$ & $\begin{array}{l}-0.121 \\
(0.296)\end{array}$ & $\begin{array}{l}-0.057 \\
(0.268)\end{array}$ & $\begin{array}{c}0.439 \\
(0.246)^{*}\end{array}$ & $\begin{array}{c}0.542 \\
(0.309)^{*}\end{array}$ & $7.00 * * *$ \\
\hline $\begin{array}{l}5 \text { - std. "adjusted" poverty isolation index } \\
\text { (excluding tracts with over } 60 \% \text { in college) }\end{array}$ & $\begin{array}{l}-0.356 \\
(0.216)^{*}\end{array}$ & $\begin{array}{l}-0.054 \\
(0.220)\end{array}$ & $\begin{array}{l}-0.017 \\
(0.200)\end{array}$ & $\begin{array}{c}0.328 \\
(0.173)^{*}\end{array}$ & $\begin{array}{c}0.432 \\
(0.217)^{* *}\end{array}$ & $12.20^{* * *}$ \\
\hline $\begin{array}{l}6 \text { - std. poverty isolation index } \\
\text { (using all census tracts but excluding } \\
\text { the "near" poor) }\end{array}$ & $\begin{array}{l}-0.917 \\
(0.545)^{*}\end{array}$ & $\begin{array}{l}-0.244 \\
(0.537)\end{array}$ & $\begin{array}{l}-0.119 \\
(0.485)\end{array}$ & $\begin{array}{c}0.794 \\
(0.452)^{*}\end{array}$ & $\begin{array}{c}0.960 \\
(0.564)^{*}\end{array}$ & $5.99 * *$ \\
\hline $\begin{array}{l}7 \text { - std. poverty isolation index } \\
\text { (excluding census tracts with over } 60 \% \text { in } \\
\text { college and the "near" poor) }\end{array}$ & $\begin{array}{l}-0.758 \\
(0.475)\end{array}$ & $\begin{array}{l}-0.105 \\
(0.473)\end{array}$ & $\begin{array}{l}-0.030 \\
(0.429)\end{array}$ & $\begin{array}{c}0.703 \\
(0.378)^{*}\end{array}$ & $\begin{array}{c}0.933 \\
(0.476)^{* *}\end{array}$ & $8.99 * * *$ \\
\hline \multicolumn{7}{|l|}{ Racial Segregation Indices } \\
\hline $\begin{array}{l}8 \text { - std. racial isolation index } \\
\text { (using all census tracts) }\end{array}$ & $\begin{array}{c}-0.628 \\
(0.368)^{*}\end{array}$ & $\begin{array}{l}-0.147 \\
(0.373)\end{array}$ & $\begin{array}{l}-0.067 \\
(0.337)\end{array}$ & $\begin{array}{c}0.554 \\
(0.290)^{*}\end{array}$ & $\begin{array}{c}0.687 \\
(0.342)^{* *}\end{array}$ & $12.93 * * *$ \\
\hline $\begin{array}{l}9 \text { - std. "adjusted" racial isolation index } \\
\text { (using all census tracts) }\end{array}$ & $\begin{array}{c}-0.468 \\
(0.273)^{*}\end{array}$ & $\begin{array}{l}-0.111 \\
(0.277)\end{array}$ & $\begin{array}{l}-0.051 \\
(0.251)\end{array}$ & $\begin{array}{c}0.412 \\
(0.215)^{*}\end{array}$ & $\begin{array}{c}0.511 \\
(0.257)^{* *}\end{array}$ & $12.52^{* * *}$ \\
\hline $\begin{array}{l}10 \text { - std. racial dissimilarity index } \\
\text { (using all census tracts) }\end{array}$ & $\begin{array}{c}-0.380 \\
(0.209)^{*}\end{array}$ & $\begin{array}{l}-0.108 \\
(0.218)\end{array}$ & $\begin{array}{l}-0.055 \\
(0.198)\end{array}$ & $\begin{array}{c}0.325 \\
(0.174)^{*}\end{array}$ & $\begin{array}{c}0.387 \\
(0.214)^{*}\end{array}$ & $15.24 * * *$ \\
\hline
\end{tabular}


Table VI - 2SLS Regession Coefficients on Segregation Index Using Additional Instruments

\begin{tabular}{|c|c|c|c|c|c|c|}
\hline & \multicolumn{5}{|c|}{ Dependant Variable } & \multirow[b]{3}{*}{$\begin{array}{c}\text { F-stat } \\
\text { on instr. }\end{array}$} \\
\hline & \multirow{2}{*}{\multicolumn{2}{|c|}{$\begin{array}{l}\text { standardized standardized } \\
\text { burglary rate larceny rate }\end{array}$}} & \multicolumn{2}{|c|}{ standardized } & \multirow{2}{*}{$\begin{array}{l}\text { standardized } \\
\text { d aggravated } \\
\text { e assault rate }\end{array}$} & \\
\hline & & & $\begin{array}{l}\text { motor vehicle } \\
\text { theft rate }\end{array}$ & $\begin{array}{l}\text { standardized } \\
\text { robbery rate }\end{array}$ & & \\
\hline $\begin{array}{l}\text { Instruments: (i) Fraction Public Housing } \\
\text { given 'in-kind', (ii) Fraction of Local }\end{array}$ & & & & & & \\
\hline $\begin{array}{l}\text { Public Revenue Received from St. or Fed. } \\
\text { std. poverty isolation index } \\
\text { (excluding tracts with over } 60 \% \text { in college) }\end{array}$ & $\begin{array}{l}-0.672 \\
(0.429)\end{array}$ & $\begin{array}{l}-0.053 \\
(0.434)\end{array}$ & $\begin{array}{c}0.002 \\
(0.394)\end{array}$ & $\begin{array}{c}0.643 \\
(0.343)^{*}\end{array}$ & $\begin{array}{c}0.886 \\
(0.433)^{* *}\end{array}$ & $10.69 * * *$ \\
\hline $\begin{array}{l}\text { Instruments: (i) Fraction Public Housing } \\
\text { given 'in-kind', (ii) Fraction of Local }\end{array}$ & & & & & & \\
\hline $\begin{array}{l}\text { Public Revenue Received from St. or Fed., } \\
\text { (iii) Number of municipalities in MSA } \\
\text { std. poverty isolation index } \\
\text { (excluding tracts with over } 60 \% \text { in college) }\end{array}$ & $\begin{array}{l}-0.667 \\
(0.429)\end{array}$ & $\begin{array}{l}-0.050 \\
(0.434)\end{array}$ & $\begin{array}{l}-0.011 \\
(0.394)\end{array}$ & $\begin{array}{c}0.639 \\
(0.343)^{*}\end{array}$ & $\begin{array}{c}0.884 \\
(0.433)^{* *}\end{array}$ & $7.09 * * *$ \\
\hline Instruments: (i) Fraction Public Housing & & & & & & \\
\hline $\begin{array}{l}\text { Public Revenue Received from St. or Fed., } \\
\text { (iii) Number of municipalities in MSA, } \\
\text { (iv) Number of 'long' Rivers in MSA } \\
\text { std. poverty isolation index } \\
\text { (excluding tracts with over } 60 \% \text { in college) }\end{array}$ & $\begin{array}{l}-0.608 \\
(0.429)\end{array}$ & $\begin{array}{c}0.205 \\
(0.424)\end{array}$ & $\begin{array}{l}0.180 \\
(0.387)\end{array}$ & $\begin{array}{c}0.663 \\
(0.346)^{*}\end{array}$ & $\begin{array}{c}0.991 \\
(0.439)^{* *}\end{array}$ & $5.11^{* * *}$ \\
\hline $\begin{array}{l}\text { Instruments: (i) Fraction of Local } \\
\text { Public Revenue Received from St. or Fed., } \\
\text { (iii) Number of municipalities in MSA, } \\
\text { (iv) Number of Rivers in MSA }\end{array}$ & & & & & & \\
\hline $\begin{array}{l}\text { std. poverty isolation index } \\
\text { (excluding tracts with over } 60 \% \text { in college) }\end{array}$ & $\begin{array}{c}-1.073 \\
(0.638)^{*}\end{array}$ & $\begin{array}{l}-0.602 \\
(0.605)\end{array}$ & $\begin{array}{l}-0.410 \\
(0.555)\end{array}$ & $\begin{array}{c}0.671 \\
(0.464)\end{array}$ & $\begin{array}{c}0.423 \\
(0.546)\end{array}$ & $3.64 * *$ \\
\hline
\end{tabular}

